Portland State University

PDXScholar

$1-1-1965$

\title{
Extracurricular activities in secondary schools of Washington County, Oregon; a field study.
}

Alan R. Martin

Portland State University

Follow this and additional works at: https://pdxscholar.library.pdx.edu/open_access_etds Let us know how access to this document benefits you.

\section{Recommended Citation}

Martin, Alan R., "Extracurricular activities in secondary schools of Washington County, Oregon; a field study." (1965). Dissertations and Theses. Paper 226.

https://doi.org/10.15760/etd.226

This Thesis is brought to you for free and open access. It has been accepted for inclusion in Dissertations and Theses by an authorized administrator of PDXScholar. Please contact us if we can make this document more accessible: pdxscholar@pdx.edu. 
AN ABSTRACT OF THE FIELD STUDY OF

Alan R. Martin for the Master of Sclence in Teaching

Date fleld study is presented:

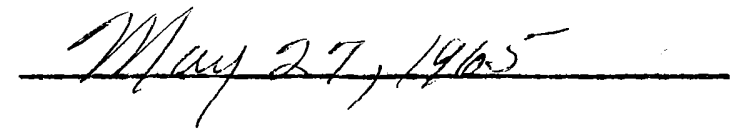

Title: Extracurricular Activities in Secondary Schools of Washington County, Oregon

Abstract approved:

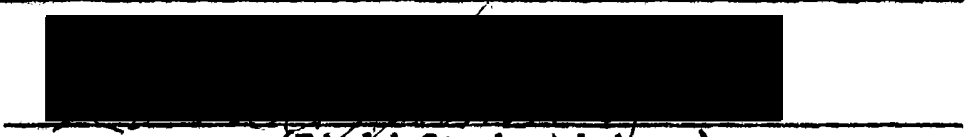

(Filid Study Advi(ser)

The object1ves of this study were to, (1) review the opinions of contemporary American educators regarding activity programs in our secondary schools; (2) Investigate the activity programs currently provided in the juntor and senior high schools in Washington County, Oregon; and ( 3 ) offer some suggestions based upon this information. The literature in this fleld, although somewhat limited, except for perlodicals, acqualnted the reader with the general area and provided a basis for the review and study of the present practices in Washington County.

The data concerning the practices in the schools studied was obtained through a questionnalre which was personally distributed and collected. The results were tabulated on 22 tables from which a narrative synopsis of pertinent information was drawn. For example, at the funtor high level, five schools engage in interscholastic sports; all elght schools have assemblies; three schools maintain a homeroom activity; all elght schools offer vocal music; and the two largest schools have more special interest clubs than any of the others. At the senior high level, all schools engage in interscholastic athletic competition; three schools have intramural sports; two schools do not have a maxching band; and six schools publish more than yearbook and newspaper. 
As a result of the review of what is currently done in the secondary schools of Washington County, and viewed in the perspective gained by the study of the Literature in this field, ten suggestions that might Improve the current programs in some schools are provided for the decision-making personnel of the school districts and schools of the County. The highlights of these suggestions are:

1. That each school establish criteria by which it annually evaluates its activity program.

2. That workshops be establiahed to discuss student needs.

3. That a census of both student participation and teacher sk111s be taken.

4. That junior and senior high schools work closely to allow beginning skills and interests to be carried over in the advanced grades.

5. That school districts investigate programs in other geographlcal areas and make activity information avallable to those interested.

6. That schools provide a wide range of activities that may offer carry-over recreational possibilitles for adult life. 
APPROVED :

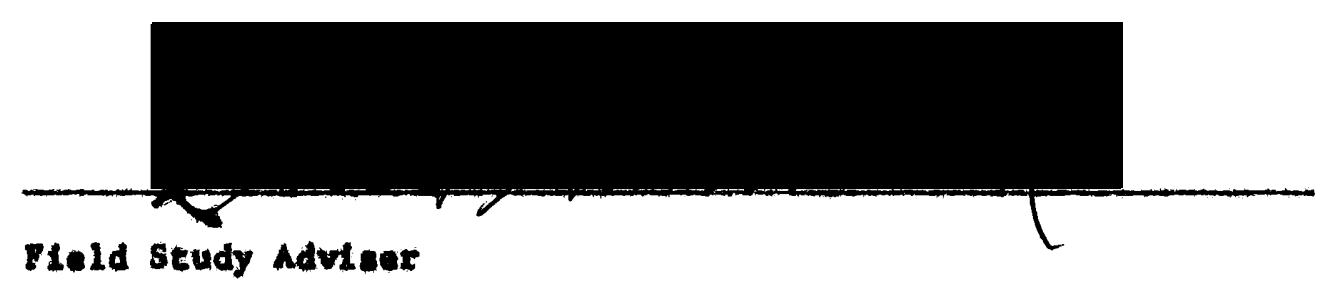

RLeld Study Adviear

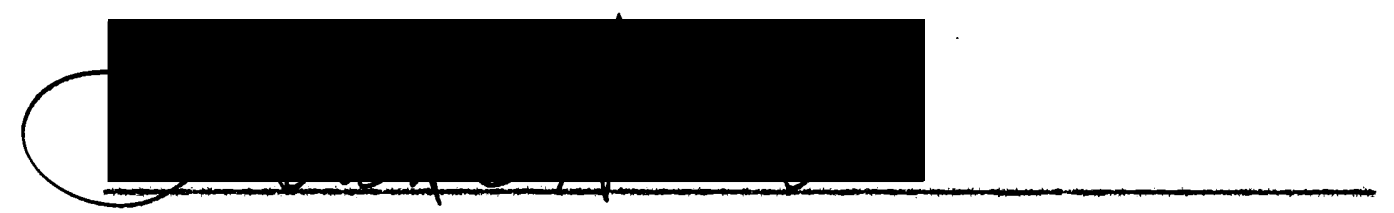

Adminfetrative offleer, Department, Division or School

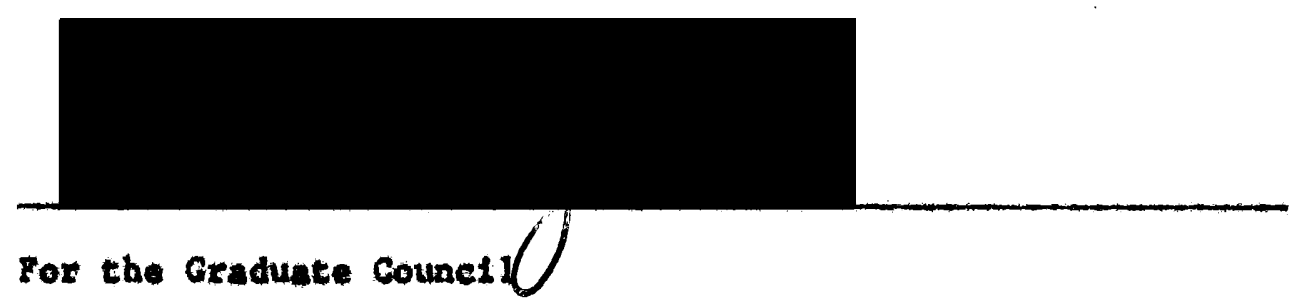

Date E1eld study is presented: May 27, 1965 


\title{
EXTRACURRICULAR ACTIVITIES IN SECONDARY SCHOOLS \\ OF WASHINGTON COUNTY, OREGON
}

\section{by}

ALAN R. MARTIN

\author{
A FIELD STUDY \\ Presented to the Division of Education \\ and the Graduate Council of Portland State College \\ in partial fulfillment \\ of the requirements for the degree of \\ Master of Science in Teaching \\ June 1965
}


TABLE OF CONTENTS

I. PURPOSE . . . . . . . . . . . . . . . . . 1

II. LITRRATURE IN THE FIELD OF SCHOOL ACTIVITIES. . . . . . . . 6 III. LITERATURE IN THE FIELD OF SCHOOL ACTIVITIES (continued) VALUES AND DANGERS OF ACTIVITIES. . . . . . . . . . 12

IV. LIMTTATIONS OF THE STUDY. . . . . . . . . . . . . 20

V. FIELD INVESTIGATION. . . . . . . . . . . . . . . 22

Key to Tables. . . . . . . . . . . . . . . . 24

VI. SYNOPSIS OR FIELD INVESTIGATION. . . . . . . . . . . 38

vII. SUGGESTIONS. . . . . . . . . . . . . . . . 45

BIBLIOGRAPHY. . . . . . . . . . . . . . . . 47

SUPPLEMENTARY BIBLIOGRAPHY. . . . . . . . . . . . . 4 48

APRENDIX. . . . . . . . ................ 50 


\section{LIST OF TABLES}

TABLE

PAGE

I. Oregon Curricular Offering by Grada Leval .......... 3

II. Junier High Athletics ..................... 25

III. Junlor High Assemblien .................... 26

IV. Juntor High Homeroem ...................... 26

V. Juntor High Muste-Drume-Speech ............... 27

vi. Juntor High Publication ................... 27

vII. Juntor High seholarshtp................... 28

vIII. Junior High Service and Welfare................ 28

IX. Juntor High Social ...................... 28

X. Junior High Studont Covarmant. ................ 29

XI. JunLor High Trips ......................... 29

XII. Juntor High spectal Interest Groups ............. 30

XIII. Bantor Hgh Athlettes..................... 31

XIV. Sentor HIgh Assemblies ................... 32

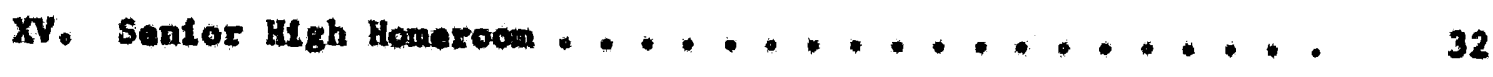

XVI. Sentor High Hustc-Drome-Bpeech . .............. 33

XVII. Sentor High scholarshlp .................... 33

XVIII. Sentor Hgh Publicatlons .................. 34 
TABLES (continued)

TABLE

PAGE

XIX. Sentor High Service and Welfare ............. 34

XX. Sentor High Soclal .................... 35

XXI. Senior High Special Interest . . . . . . . . . . 36

XXII. Senior High Trips ..................... 37

XXIII. Senfor High Student Government . . . . . . . . . . 


\section{ACKNOWLEDGMENTS}

The author wishes to express his greatful appreclation and thanks to the superintendents and secondary school principals of Washington County, Oregon, for their assistance and allowing the use of their buildings for gathering information; to Dr. Errett Humel of Portland State College for his helpful advice, Inviluable suggestions, and patience, to Miss Patricia Byrd of the Portland State College Library for her friendly help in locating material which was of special ald; to those many Individuals who, with a word or cumment, offered encouragment; and finally, to my family, especlally my grandmother, Mrs. Laura Barnes, whose falth and wise counsel was a sustaining factor during the writing of this study.

A. R. M. 


\section{CHAPTER I}

\section{PURP0s:}

the purpose of this otudy is to review the opintons and experfences of sone edveator reghrding activity or co-curricular programs in public shools and to briefly survey the cetivity programs that are currently avallable to students in the secondary sehools of in Oregon county.

The Amertean public secondary school (Juntor and sentor high achool) his been given, by the eftizens of this notion, part of the responstbility of prepiring adolescent boy and glzls for adult roles and for further eduettive experience. It attempting to accomplioh these complementary task, the secondiry schools have established certain curricular standerds. Wach state system of publle secondary education has sot its om spectfic requirments for promotion and graduation; but nationdily our secondary schools tend to follow general pattern. Oregon's requirements, we listed in the Gulde to secondery Edusction and the Guide to Juntor High School Eduction in Oregon, are:

Graduation Requitrenents The state Board of Iducation requit re eortein oubjects for graduation from a standard high school. Mineteen unlts re now requlrad for graduation from any standurd high school in Oregon. These nineteen units shall inelude the following: 
3 Untes of Engligh . .

2 Untte In Soelel studies. .

2 Units In Health Instruction and Phyleal Education . -

1 Unit In Sclence

Inte In Mathematies

Language Arts is required subject throughout the three years of juntor high school. .

soelal studies is required subject in the

seventh and olghth grades and is usually required

loeally in the ninth grade.

Mathemetles is also a required oubjoct in

gxades seven and efght of the juntor high school. .

setence should be a regulined subject for the

three grades of the juntor high sehool. .

Health and thysteal Eduantion are Included hexe

In one group...

Nommaktng and Induatrial Arts dre escential

paxts of the Junior high school program and a

udninuen of one year of practieal arts hould be

Included in the curriculum of the seventh and elghth

grades. These subjects are offered as electives in

the ninth grade.

Muste 16 a part of general education and is

normally required for at leat one semester in the

deventh grade..

Forelgn Langueges should be offered in grades seven, etght, and nine

Axts and Crafts is an Integral pert of general

educetion and hould be avallable to sudents on ail

grede levels. 2

The following chart of curricular offerings for

Oregon Juntor high sehools is esentall based upon

- seven-pertod day, but $1 t$ may be adapted to alx-

pertod day by judielous subject combinettons. In

thts chart, the currteular areas 1toted...

constltute the usuni mintmum baste program for oach

grade level.

Istate Department of Bducation, Gulde to sceondary gducation in Oregon, 1961, p. 16.

28tate Department of Educetion, Gulde to Junlor High school Education in Oregon, 1963, pp. 5-6. 
TABLE I

OREGON GURRTGULAR OREERINOS BY GRADE LEVBL, 1

\begin{tabular}{|c|c|c|}
\hline Grade 7 & Grade 8 & Grade 9 \\
\hline 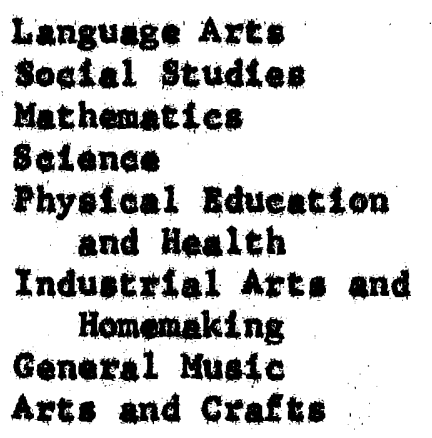 & 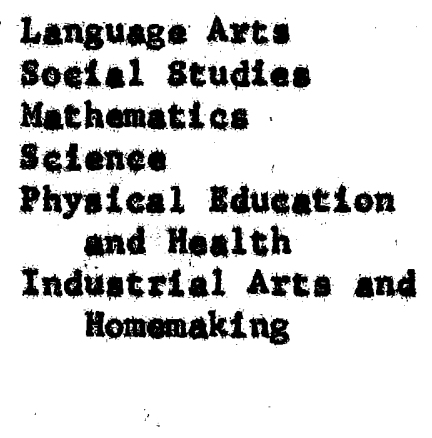 & $\begin{array}{l}\text { Language Arts } \\
\text { Soetal studies } \\
\text { Mathematice } \\
\text { setence } \\
\text { Phyotenl Rducation } \\
\text { and Health }\end{array}$ \\
\hline
\end{tabular}

Beyond the spectflc cas ree requitements for ench grade level or for graduation, Oregon public secondary schools hive expanded the learning opportunities for students by a two-fold progran of elective eurelcular opportunities. The first part of thls progran Ineludes work for whteh academle eredit is earned, and the second part conststs of those ectivities in which student particlpetion is voluntary, with no acedente eredit. Most of the euthors reforred to in this atudy agree that aetivitles, elther as extenstons of aeadente subjects or of a purely soetal or interest nature, provide opportunities for benefielal learning experlences wheh belp accomplish the responsibl lities mentioned on page 1.

The Oregon Rovised statutes do not grent spedfic permisston to this state's shools to provide for activitles. Hovever, there are laws that apply to school ativities. For example, state laws give permisalon

$1_{\text {Ibid. }}$ 
to school. to cherge fees for edueational programs that are not part of the regular school program, require drivers of school buses transporting students to of from any sehool sponsored activity to submit to spectal tralning and examinations, stipulate that only certifled school personnel be in charge and be responsible for school sponsored programs, et cetera. Thus through a Henlltonian" viev of the Oragon lawe, the activity prograns appear to be well establithed legally. Since the Ineopton of the expended currteulum by the Inclusion of lective elasses and the ectivity program, the activity concept has changed from suppression to exploltation: suppression to the extent that activities now commonly found In many of our secondary sehools were at one time not allowed on public sehool property or duelng school time. axplottation to the axtent that som activities beame a ource of communtty entertalnment ox chool ftnances. The majortey of public secondary sehools in Oregon and the United states today have rome type of student activity progrom in thetr overeli sehool currteulum, and this progrem generally fulls somowhere betweon the two extremes mentioned. In Oregon, as In 11 flfty states, there is a voluntary organitation that overbees the Interseholaste compettion and other cooperative progtans, The Oregon agency is called the oregon sehool Activitles Assoatation. The Oregon orgmization to member of the National Federation of state Mgh school Athlette Associations. The Oregon ageney's dutles are spelled out in Artlele II, Section 1 of 1 to condeftution. 
Section 1. The object of this organisation hall be to protect the interests of high, junlor high, and elementary schools belonging to the Association, and to regulate interseholastic activities, such as meets, contents, or tournuments that embrace schools of the state of Oregon, or sections thereof, and to provide and operate Mutual Benefit. Program for the beneflt of the puplls of high, Junlor hlgh, and lementary ehools. 1

Activities of the organiation Include:

1. Brminition and certification of offletals.

2. Egtablishment of acedente requiremente for athletic pertielpation in interseholavtle competition.

3. Eatublishment of school classifteation based upon student population.

4. Lotablighment of tournmente in several activitie to deteanine champlonshlp.

5. Bnforcement of rules and regulation pertalning to interecholeste pertiolpation.

As Indicated in the oponing paragraph thl atudy wil present some thinking of educationel leaders and wil then pleture the activitles that are avallable to students in the secondary sehools of an Oregon county, Finally, a few recommendations that intght ald those zesponstble for dectsion-miking in the public schools wil be suggested.

loregon School Aetivities Assoctation, Contthution and By-Late. $1964, p .5$. 


\section{CHAPTBR II}

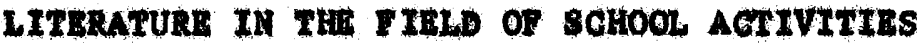

Books published in the fleld of public school activities do not appear to be as numerout as othex areas of edueation. Only eight books of consequence could be loetted. Of those, two were published in the enrly 1930 's and the rest during the seven-year pertod between 1952 and 1959. There are additionn1 texts wose sope Is limited to one aspect of the activity program, such as cheerleading or school publications,

The majortty of eurrent witinge concerning sehool setivities are to be found in the pertodicals. A recent axmination of U1xichle Betodich 1 DLrectory ${ }^{1}$ revenled that no lese than 74 teles pertalning to sehool activities ax aubjects which havo activities are currently betng publishod. This number does not lnclude the sepurate axticles that may appear from time to time in vantous fournal coneerned wth general educetive problems.

Reviey of the avaflable texts about sehool activities was followed by Investigation of eurrent witinge in the perlodicals. Basle Information gathored from the texts, whil the pextodicals augmented and supplanted what wa galned from the flrot sources. Perlodical materlal had the advantage of being eurrent wherens the baste sources

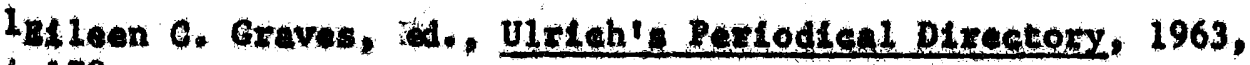
Pp. 164-179. 
were at least ix years old. Further information was gathered from agency publications on education, school activttles, and state and federal bureaus.

The ectivity programs as they are found in our sehool teday are an Innovation of the past century. Activites usually began as clubs ar teams and as such recelved no help from the schools. As time passad and communtty eceptance of ectivities gtew, the whool gave the studente a plece to meet and finally took over the activity and provided advisors.1 In 1919 Columbia Univertey Touchors College offered the firet professtonil course in extro-curticuler cetvitles. "Dr. Blbert $K$. Fratwell, reforred to by many as the father of the modarn extracurrteular movement, tought the course."n2 Fexaphrastng Fredertek, 3 the hIstorical development of student activites his followed these fIve general steps:

1. Activities flourish in settled, favored segment of soelety.

2. Literany and sorts activitles are given flute offlelal acceptince.

3. Otflelal polley toward activitles w11 vary from location to location. Some 111 uppross whlle others explott.

4. secondary sohoole usually: follow the lead of the colleges or untverstetes.

5. Nompublle acheols are generally further along in thetr development of activities then the publle sehools.

lGrace Grahan, "student Aotivitles--An Overview and Rationale,"

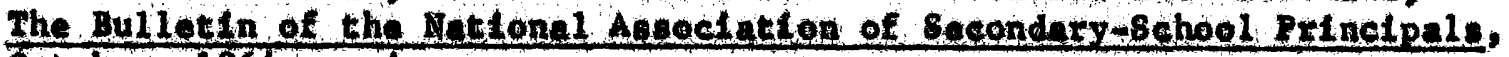
october. 1964, P. 4.

2Grahem, p. 10.

3Robert w. Fredertek, the Thltd Currteulum, 1959, p. 31 . 
It is suggested that the success of the modern activity

program has been due to some, if not all, of the following reasons:

1. Parente enjoyed seeing chlldren perform.

2. Teachers enjoyed working wth adolescents in informal activities.

3. Students liked activitles.

4. Principals were happy because the parents, teachers, and students vere happy.

5. America was becoming urban and the fantly could not keep the chtldren busy.

6. Hot unt11 recent times were there many communtty agencles for recreation.

7. Many of the students were too old for gemes and too young for work.

8. Some drop outs were prevented in interest in an activity.

From the time when students wanted to engage In some activity that the school did not want or would not support, to today, when a great variety of activities are part of the secondary school's program, the general attitude of the schools and the publle has changed greatly. Today, activitles are not only accepted but even encouraged by people both in and out of the education profession.

Amert Gans generally, and Amertcan students and educetoxs specifically, have eceepted the dostrablilty of almost il kinds of student activities. That battle has been won in every type and level of educational inititution, 2

In recent decades activity program have gained in atatus because college directors of adintislons, even in prestige ahools, Blve preference to applicants who have not only good academic records but 180 good records of partialpation in ectivitles. Bmployers too are sometimes interested In the activity records of prospective employees. 3

\footnotetext{
${ }^{1}$ Graham, pp 4-5.

${ }^{2}$ Frederlck, p. 95.

3raham, p. 5 .
} 
What reasons can be offered for incluston and matritenince of activitide in th modern Amertean sehool? Aside from the opectfle values mentloned in Chapter III, there are reoults Inherent in the activity progumen which are of such beneflt that more cen be gained by having the aetivitles as part of the school pregran than by not having the ativities. Mnny sectffe reasons can be offerad, but perhaps the bett are to be found In Yon's article concerning the contribution of school activitios. Yon foels that school activities help bring about:

1. Better rapport between the teacher and student,

2. A feeling of trust and understending between the teachare and student.

3. Informil meeting between the teacher and student. Land $60: T$

4. Broiden the hortitens of the students.

5. Lead to fuller developarnt of the student. 2

The suecese of the modern activity progrem has not been won whout a prtee. It has been the expertence of any schools that, in the limb fmon obseurtty to recognition, ativitles can be overamphasted to the potnt of exploltution. ${ }^{3}$ Th1s to particulerly true

Isee Graham, pp, 2 and 10; Fredertek, P. 49, glbert K. Fratwe11, Extre-Currtcular Aetivitles In Secondery Schools, 1931, P, 4; and Frankin A. MIII6, James H. Moyer, and Robert B. Batrlek, Rlannlns Student Aectuteles, 1956, p. 49.

2John F. Yon, "What do Aetivities Contribute?," Sehool Activities, September, 1963, p. 21.

3pttfalls of spectflc activities are desexibed in Ghepter III. spectfle reference $1 \mathrm{~s}$ made here to the perfection sometimes demanded In drematic and musleal presentetions and the enphesis upon winning rather than purttelpation sometimes found in competittve athlettes. 
of activitien whteh have uppos to meny spectators, It is espectolly true when the locel commity, whose interest In the schools is underatandably grest, makes unzensonable denands upon the schools, As Grahum polnts out,

We Aso regerd coninlty Interest in the school as useful bectuse the school depends upon the community for Etnonetal support. Agaln ehis incerest is not an unalxad blessing because the settvity program may be distorted by the desire to furnish good entertel meent for local cltsen rathet than good educetion for young people. 1

Additionalty, authors in the fleld of studene activities have difeleulty in defining those supplemental school programs termed activitios. As MIIler, Moyer, and Patriek atate, "An omptrieal definteton 18 difficult to phrase and 10 usualiy very unsatisfectory,"2 Blbert Pretwel1 sald, NGitra-curalcular activitles moy bo defined as those Iegltimate aetivitios of the sehool not otherwise provided for." 3 The diffleulty In drafting en adequate definition lies in the fact that one definttion 111 simply not do the required task. Aetually two definttions com closer to describing the scope of the toplc. First, there ts the definition of the atudent ettvitios which are ". . those echeol gettvitles voluntertiy engaged in by students, whleh hove

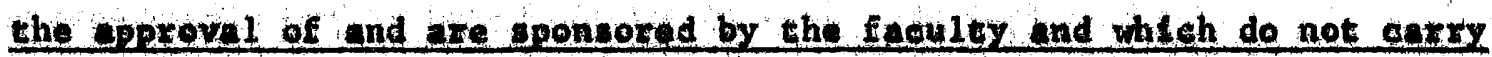

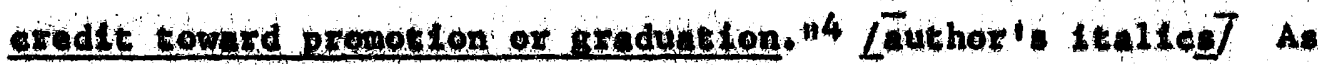

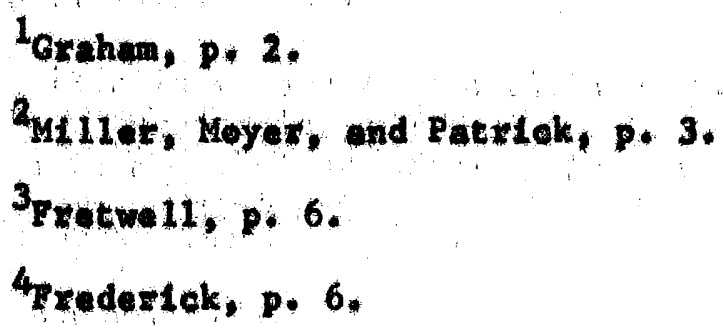


distingulshed from formal academie classes, these activities are: student centered (students are responsible for planning), have less formal structure, earn no acedemic credit, and give greater attention to personal and soctal gutdance. The second definition would include the curriculum activities which are a direct extenston of a formin elassroom course which grants academtc credit, but would expressly exclude cqurses sequirad by shool regulations and the cless-required activities. This study of the planned activity expertences provided for children in secondary schools of an Oregon county will review both the school sponsored activity programs which do not provide academic credit and those activity-type programs or courses which are elective. 
LITERATURE IN THE FIELD OF SCHOOL ACTIVITIES (continued)

\section{VALUES AND DANGERS OF ACTIVITIES}

The values of education and the values of activities as listed In most of the references reveal a close relationship. Th1s is not surprising, for we cannot assume or expect that they would differ and be under the same sponsorship, nor can we assume that a school administrator would list differing goals for two programs under his supervision. "Objectives of Secondary Education," as suggested by Miller, Moyer, and Patrick, might well serve as objectives for activity programs.

1. To Develop Good Citizens . .

2. To Enable Pupils to Communicate Adequate1y ...

3. To Prepare Pupils for Economic Efficiency - .

4. To Develop Healthy Minds in Healthy Bodies . .

5. To Prepare Pupils for Family Life...

6. To Direct the Pupil's Use of Leisure Time...

7. To Develop Social Competency ...

8. To Develop a Set of Moral and Ethical Values ..

9. To Discover Special Interests and Capacities . .

10. To Develop Creative Self-expression . . . 1

As was emphasized earlier, (pages 9 and 10), community factors may pose problems of pressure upon the school to establish, maintain, or ald an educationally unsound program, one with heavy emphasis on spectator

IMllier, Moyer, and Patrick, pp. 42-48. 
activities rather than on participation activities. As Unruh pointed out in his analysis of an evaluation of football versus photography, in which photography offered more educational opportunity:

Too often decisions are not made on an impartial, objective point of view. Community pressures and traditions have often determined whether or not an activity should be initiated or retained. That this is not good for the educational advancement of the institution is clearly demonstrated in this experiment. 1

As a summary to the values of activities and criteria for the selection of these activities, Unruh and Mock offer the following guidelines for selecting activities:

1. The activity must provide optimum educational value.

2. The activity must satisfy student needs.

3. The activity must be socially acceptable.

4. The activity must serve and promote democratic ideals.

5. The activity should have carry over value.

6. The activity. must not be excessively costly either to the student or to the school.2

1. Student need.

2. Principal knows needs and leads selection.

3. Size of the school.

4. Number of available sponsors.

5. Most of the faculty should be willing to cooperate prior to Institution of the program.3.

Any school district making decisions regarding educational opportunities needs to consider both the values and dangers, or pitfalls, that are inherent in any program. McKown, in his book, Extracurricular Activities, 4 has provided the major portion of the following checklist

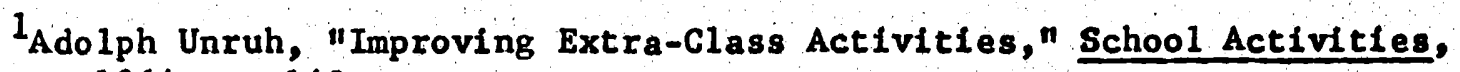
January, 1964, p. 143.

2Unruh, p. 142 .

3Albert Mock, A Manual of Student Activities, 1952, p. 9.

4Harry C. McKorm, Extracurricular Activities, 1956. 
that includes eleven categories of activities frequently found in 6chools. Authors who have written similar works support and amplify the 1tems of the checklist.

Athletics. Interscholastic competitive sports, intramural competition, mass group games, small group games, Individual

sports and games, Informal activities, and managers.

Benefits

Helps good physical development

Aids in becoming a team member

Develops good sportsmanship

Promotes school spirit

Provides publicity for the school

Refreshes the spirit, mind, and body

Promotes interest in post-high school activities

Pitfalls

Takes time away from other activities and classes

Becomes a source of physical injuries

(In addition to the above pitfalls, the following are

listed primarily against interscholastic competition.)

Emphasizes crowd pleasing

Becomes a money-making venture

Benefits few students

Expensive in terms of time and money

Becomes a source of emotional injuries

Emphasizes overspecialization

Equates "success" with winning

Promotes professionalism and commercialism

Overemphasizes coach's role

Develops poor sportsmanship

Breeds unhealthy rivalry

Benefits only boys

Assemblies. Talks by individuals, groups (from within and out-

side the school), entertainment of a musical or a dramatic nature,

forums, special days, and other like functions. 
Benefits

Unify the school

Bring together and educate in common knowledge, rules and attitudes

Encourage and augment student work

Instill desired Ideals and virtues

Widen and deepen student interests

Encourage worthy use of leisure time

Help develop and aesthetic sense in the students

Publicly recognize worth-while achlevement

Develop self-expression

Promote correct audience habits

Bring the community and the school together

Pitfalls

Emphasize perfection in performance

Assembly becomes a morality lecture

May detract from classtime

Homeroom

Benefits

Lets the teacher know the child

Provides a period of guidance

Handles routine work

Develops class pride

Pitfalls

Becomes a formal class

Becomes too informal

Coples other programs

Bound to a plan

No evaluation planned for

Music-Drama-Speech. Chorus, glee clubs, small vocal groups,

band, orchestra, class plays, debating, oratory, speechęs, and

simflar functions.

Benefits

Self expression

Clear enunciation

Develop confidence and poise

Intellectual and cultural gains

Appreciation of thoughts, feelings, and standards of others

Management of the stage and people involved

Raises dramatic standards (as opposed to "thrill" movies, etc.)

Help guide personal growth

Utilizes many school departments. 
Pitfalls

Crowd-pleasing emphasis

Those in need of the benefits may not receive them

Those who receive the benefits may not need them

Activity is too highly specialized

Emphasis on "success"

Too few students participate

Publications. School paper, magazines, annual, handbook, and

other such publications. Includes the activities of all concerned

Including reporting, composing, editing, managing, and the like.

Benefits

Unifies the school

Promotes school spirit

Encourages desirable school activities

Codifies and influences student opinion

Publicizes accurate information about the school

Allows for student expression of opinion

Allows for self expression and creativity

Develops accuracy, tact, cooperation, tolerance,

responsibility, initiative, and leadership

Promotes friendly relations among schools

Records school history

Advertises the school.

Pitfalls (concerns mostly school magazines)

Some literature is not worthy of publishing

Content is sometimes uninteresting to students

Organization is sometimes uninteresting to the students

Humor is largely taken from other publications

Editorials are sometimes sermons and moralizings of no real value

Too few students participate

Represents only a small part of the 8 chool

Expensive in terms of time and money

Scholarship. Honor roll, honor society, and other groups giving

recognition for scholastic achievements.

Benefits

Gives recognition for effort and achievement

National recognition for achievement

Pitfalls

Very slender margin for recognition

Emphasis on grades rather than learning 
Service and Welfare. Promote clean-up, fix-up days, perform

helpful duties around the school and community, help students

and visitors around the school, perform needed duties.

Benefits

Help maintain order in the school

Develop school pride

Direct students' energles into useful endeavors

Show concern for the needs of others

Serve the community

\section{Pitfalls}

Engage in "busy work"

Not many participate willingly

Social. Dances, parties, mixers, picnics, dinners, banquets, graduations, incidental meetings in the school and other such activities.

Benefits

Develops important social skills

Provides healthful and beneficlal amusement

Helps motivate school life and work

Prepares students for adult roles socially

Helps promote healthy heterosexual contacts

Pitfalls

Easily dominated by a clique

Students in need of benefits often do not attend

Assume importance in the adolescent mind out of proportion

Special Interest Clubs. Subject oriented clubs (science,

mathematics, language, commercial and the like) and all

miscellaneous clubs (camera, auto, stamp, hiking, and the 11ke).

Benefits

Deepens and widens interests

Develops important social skills, habits, and attitudes

Enrlches and motivates class work

Encourages work in areas of deep interest

\section{Pitfalls}

Club may be vocational in purposes

students may spend a disproportionate amount of time in the club

Club may be too orlented to class work 
Student Government. Student councils, associations, committees, monitors, guards, class governments, and the like.

Benefits

Prepare students for life in a democracy

Help the student to be self directive

Show the importance of social cooperation

Increase student interest in the school

Help develop school morale

Support law and order

Develop abilities and qualities

Help supervise, organize and manage school activities

Be representative in the total school

Make extracurricular work more efficient

\section{Pitfalls}

Members often elected on the basis of popularity, not ability Becomes an administrative rubber stamp

Threatens the staff and administration

Does not represent the will of the students

Trips. Field.trips, excursions, and other activities away from

the school.

\section{Benefits}

Helps students to become better acqualnted with the community Enriches and supplants the curriculum

Satisfies the youthful need to "go"

\section{Pitfalls}

Expensive in terms of time away from school

Sometimes poorly planned

The total activity program of the school may have an effect greater than that which touches the students only. It is suggested that the activity program can help not only the student, but curriculum, the school administration and the community as well. The benefits to the students have been outlined above. Possible benefits to the other three areas mentioned are outlined below:

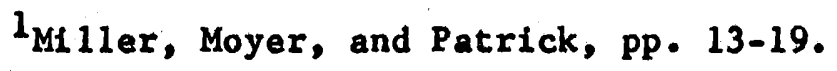


Contributions to Curriculum Improvement

1. Supplant or enrich classroom experiences.

2. To explore new learning experiences which may ultimately be incorporated into the curriculum.

3. To provide additional opportunity for Individual and group guidance.

4. To motivate classroom instruction.

Contributions to More Effective School Administration

1. To foster more effective teamwork between students, faculty, and administrative supervisory personne1.

2. To integrate more closely the several divisions of the school system.

3. To provide less restricted opportunities designed to assist youth in the worth-whlle utilization of their spare time.

4. To enable teachers to betcer understand the forces that motivate pupils to react as they do to many of the problematic situations with which they are confronted.

Contributions to the Community

1. To promote better school and community relations.

2. To encourage greater comunity interest in and support of the school.1

I Ibid. 
GHAPTRR IV

LIMTATIOAS of THE STUDY

For thts utudy sogondary sehool trelude all soparately

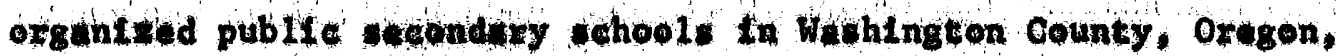
that we astrbllihed for the peltele purpose of housing, tretning and othervise edueating adeleseent boys and giwle. Tht torn ts used to Include those rehools comonly neferred to as junlor high sehools and sentor high gchools. The grade levels Ineluded in this definttion are the 7th through the 12th. The definition to so dxafted as to comply wh the requirmants for such sehools as act forth by the Oregen Stat Dopartant of Education through its offlelel pubilcutione.

The senlor of terminal high schoole chosen for this study were taken from a list of Wahington County high sehools complied by the Oregon State Dopertment of Education. The school are:

Banka

Besverton

Porent Grove

Oesten

Al11boro

Sherwood

Sunwet:

Therd

Istete Department of Bducation, 1964-65 Ozegon Sehool Directors, 1964 , PP. $53-55$. 
The funtor high schools selected for this study were taken from the same source the high schools. The schools are:

Bast H11 Isboro

Fowlex

Highland Park

LIncoln

Meadow Razk

Poynter

Twallty

Whitford

The shool activities reviewed in these school are those programs that can be classifled under the two-fold defthition given on pages 10 and 11: school activities engaged in voluntarily by the students and activities of non-requited elasses.

${ }^{1}$ IbLd. 


\section{GHAPTER V}

\section{FIBLD INVRSTICATION}

Thte chapter represents the compllation of the informatton gatned through the Invertigation of student wetivitlos of secondury school in Washington County,

Because of the wde range of studont population in these schools, the questlonnatre (Appendix) had to be dealgned so it eould be used is effectvely in sehool of approximutely one hundred student as it could in sehools of approximately two thousend and at the san time oample a broad spectrum of activities. The quentionnitre was also designed to be used in personal intorview. This we done for two reasons: (1) returns of $100 \%$ were sosured, and (2) intexpretations of terminology and procedure were made "on the apot" In order to keep mi uunderstanding at animum.

Atter the questionalre was destgned, each seheol was contacted and an oppolntmont we requested with elther the prinelpal or his ropresent:tive. During the Intelal interviow the purpotes of the study and the Interpretation of the testing inctrument were discused and explatned. The questionnulre was then laft wh the shool adninistrator whth the request that the desired infomation be complled and recorded at his convenience, After the lapse of bbout one week's tine the questionnalxe were gathexed for the most part by another parsonal vist. Each 
sehool contected in the survey returned the completed form.

The complied data, organised in 22 tables, pletures the extracurricular activities in which the young poople from these schools presently ongege. The data is organiad by type and title of activity in the levels of sehool (juntor and sentor htgh). Factore limiting partielpation in ench of the cetvities and whether of not aeademie credit is carned are ineluded in the product.

The findings wepresented in the following tebles axe coded to the key below. Tables II through XII pleture the student ectivity programs found in the juntor high schools of Washington County, and Tables XIII through uIII provide the date for the oentor high schools. 
KBY TO TABLES

Sehools

\begin{tabular}{|c|c|c|c|}
\hline Symbol & Sehool Nome & $\begin{array}{c}\text { student } \\
\text { Populition }\end{array}$ & $\begin{array}{l}\text { Crade } \\
\text { Levels }\end{array}$ \\
\hline $\begin{array}{l}a \\
b \\
b \\
b \\
b\end{array}$ & 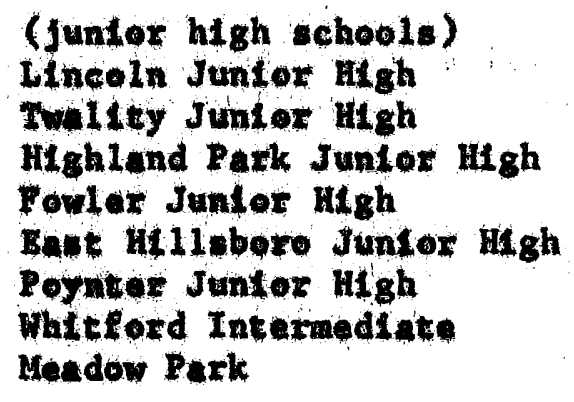 & $\begin{array}{l}298 \\
373 \\
376 \\
441 \\
676 \\
780 \\
928 \\
993\end{array}$ & $\begin{array}{l}7-8 \\
7-8-9 \\
7 \\
7-8-9 \\
7-8-9 \\
7-8-9 \\
7-8 \\
7-8\end{array}$ \\
\hline $\begin{array}{l}1 \\
2 \\
3 \\
4 \\
5 \\
6 \\
7 \\
8\end{array}$ & 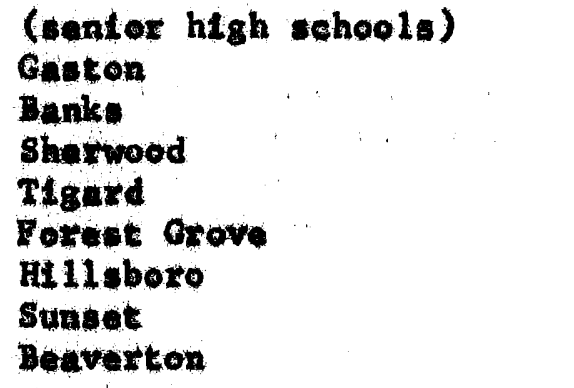 & $\begin{array}{r}113 \\
233 \\
304 \\
737 \\
872 \\
1,299 \\
1,888 \\
2,232\end{array}$ & $\begin{array}{l}9-10-11-12 \\
9-10-11-12 \\
9-10-11-12 \\
10-11-12 \\
9-10-11-12 \\
10-11-12 \\
9-10-11-12 \\
9-10-11-12\end{array}$ \\
\hline
\end{tabular}

Fartlelpation Factors

Syabol

Partielpation Factors

Beys only

Qtila only

Boys and glels

Money neceseary for paxticipation

Prerequistte othor than money

Achdente eredt enrned in betivity 
TABLE II

JUNZOR HIGH ATHLETLCS

\begin{tabular}{|c|c|c|c|c|c|c|c|c|}
\hline Activity rtele & $\mathbf{a}$ & $\mathbf{b}$ & c. & a & e & $t$ & $\mathbf{8}$ & $\mathbf{h}$ \\
\hline $\begin{array}{l}\text { Interschol astic } \\
\text { Football (flag) } \\
\text { Basketbell } \\
\text { Track and Fleld } \\
\text { Baseball } \\
\text { Wrestiling } \\
\text { Swimming } \\
\text { Tennis } \\
\text { Colf }\end{array}$ & $\begin{array}{l}+\$ \# \\
+\$ \# \\
+\$ \# \\
+\$ 4\end{array}$ & $\begin{array}{l}+\$ \\
+\$ \\
+\$ \\
+\$ \\
+\$ \\
8 \\
4 \\
+8\end{array}$ & & $\begin{array}{l}+ \\
+ \\
+ \\
+ \\
+\end{array}$ & $\begin{array}{l}+\$ \# \\
+\$ 4 \\
+\$ 1 \\
+\$ 1 \\
+\$ 4\end{array}$ & $\begin{array}{l}+\$ \\
+\$ \\
+\$ \\
+\$ \\
+\$\end{array}$ & & \\
\hline 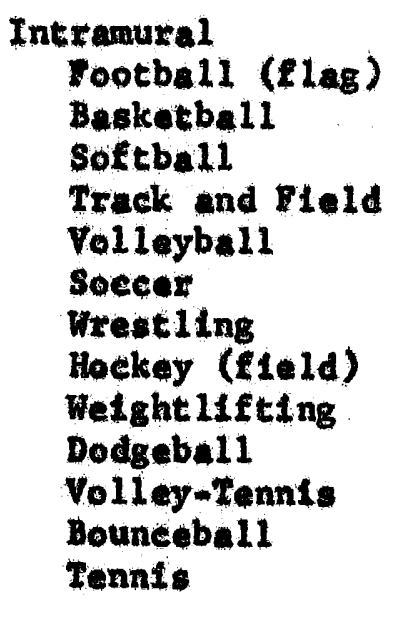 & $\begin{array}{l}8 \\
8 \\
4 \\
8\end{array}$ & $\begin{array}{l}+ \\
+ \\
+\end{array}$ & $\begin{array}{l}+ \\
6 \\
6 \\
6 \\
4 \\
6 \\
0 \\
0\end{array}$ & 0 & $\begin{array}{l}0 \\
0 \\
0 \\
+\end{array}$ & $\begin{array}{r}+\$ \\
4 \\
+\$\end{array}$ & 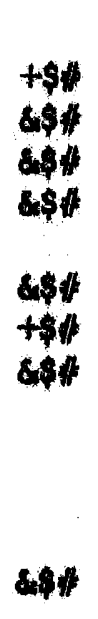 & $\begin{array}{l}+ \\
6 \\
+\end{array}$ \\
\hline $\begin{array}{l}\text { Informal Athletles } \\
\text { Badminton } \\
\text { Pfng Fong } \\
\text { Tumbling } \\
\text { Volleyball } \\
\text { Archery } \\
\text { Deek Tennis } \\
\text { Tennis } \\
\text { Trampoline } \\
\text { Horse Shoes } \\
\text { Bhufelebourd } \\
\text { 2-Square } \\
\text { Playday }\end{array}$ & $\begin{array}{r}8 \\
+\end{array}$ & 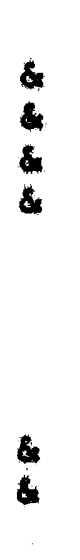 & $\begin{array}{l}8 \\
8\end{array}$ & 0 & $\frac{4}{*}$ & $\begin{array}{l}8 \\
88\end{array}$ & $\begin{array}{l}0 \\
0 \\
0 \\
0\end{array}$ & 6 \\
\hline
\end{tabular}


TABLE III

JUNIOR HIGH ASSEMBLIES

\begin{tabular}{|c|c|c|c|c|c|c|c|c|}
\hline Activity Titlo & $a$ & $\mathbf{b}$ & 8 & 4 & e & t & $\mathbf{8}$ & h \\
\hline \multirow[t]{2}{*}{$\begin{array}{l}\text { Acsemb1tes } \\
\text { Selenee Falx }\end{array}$} & 4 & 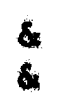 & 4 & 8 & $\&$ & $\&$ & * & 6 \\
\hline & JunI & $\begin{array}{l}\text { TABL } \\
\text { MTO }\end{array}$ & $\begin{array}{l}\text { IV } \\
\text { HOME }\end{array}$ & OM & & & & \\
\hline Aetivity Itele & 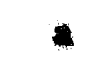 & b & e & $d$ & - & $\mathbf{f}$ & 8 & $\mathbf{h}$ \\
\hline Homeroom & & & $s$ & & & & 8 & 8 \\
\hline
\end{tabular}


TABLE V

JUNIOR HTGH MUSIC-DRAMA-SPEECH

\begin{tabular}{|c|c|c|c|c|c|c|c|c|}
\hline Actifity rttle & 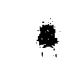 & b & e & d & e & $\mathbf{f}$ & $\mathbf{8}$ & $\mathbf{h}$ \\
\hline $\begin{array}{l}\text { Muste } \\
\text { Voenl } \\
\text { Chorus } \\
\text { Snall Group } \\
\text { Chols }\end{array}$ & $\frac{c}{4}$ & \& & \&* & 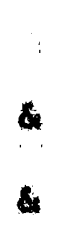 & 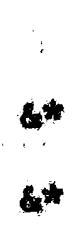 & 0 & 8 & $\alpha^{*}$ \\
\hline $\begin{array}{l}\text { Instrumental } \\
\text { Marehing Band } \\
\text { Conest Bend } \\
\text { Orohestra } \\
\text { Pop Bund } \\
\text { Dence Band } \\
\text { strtig Group } \\
\text { stage Band }\end{array}$ & 4 & 4 & 6 & $\alpha$ & 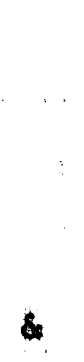 & 8 & $\&$ & 8 \\
\hline $\begin{array}{l}\text { Droma } \\
\text { Club } \\
\text { Clase Plays }\end{array}$ & 6 & & 8 & & $2^{*}$ & $\star$ & $*$ & 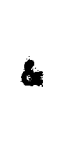 \\
\hline $\begin{array}{l}\text { Speoch } \\
\text { Public specking } \\
\text { sprech } \\
\text { Debate }\end{array}$ & $\begin{array}{l}4^{*} \\
4\end{array}$ & 4* & & 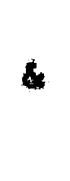 & 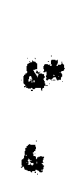 & 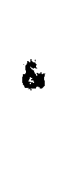 & & 6 \\
\hline
\end{tabular}

TABLE VI

JUNIOR HICH PUDLICATIONS

\begin{tabular}{|c|c|c|c|c|c|c|c|c|}
\hline Aettudey rtele & a & $b$ & 6 & $d$ & 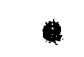 & $f$ & 8 & h \\
\hline $\begin{array}{l}\text { Xeaxbook } \\
\text { Nowepaper } \\
\text { Student Handbook } \\
\text { Student DLrectory }\end{array}$ & 6 & 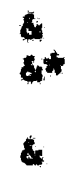 & $6 *$ & 8 & 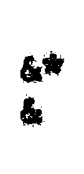 & 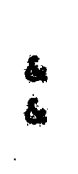 & $\&$ & $\&$ \\
\hline
\end{tabular}


TABLE VII

JUNIOR HIOH SOHOLARSHIP

\begin{tabular}{|c|c|c|c|c|c|c|c|c|}
\hline Activity $\mathrm{TLt}$ e & $\mathbf{a}$ & b & 6 & $d$ & - & $\mathbf{f}$ & 8 & $\mathbf{h}$ \\
\hline $\begin{array}{l}\text { National Honor } \\
\text { hatety } \\
\text { Honor Holl }\end{array}$ & $\&$ & $\&$ & \& & 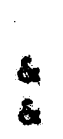 & 8 & 6 & & \& \\
\hline \multicolumn{9}{|c|}{ TABLE VIII } \\
\hline Activity Rite & $a$ & $\mathbf{b}$ & e & d & - & $\mathbf{f}$ & $\mathbf{b}$ & $\mathbf{h}$ \\
\hline 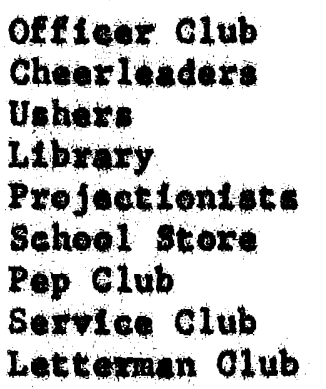 & $\begin{array}{l}0 \\
+ \\
+\end{array}$ & $\begin{array}{l}8 \\
0 \\
8 \\
+\end{array}$ & 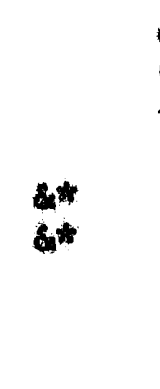 & $\begin{array}{l}8 \\
0 \\
+\end{array}$ & $\begin{array}{l}0 \\
4 \\
+ \\
0\end{array}$ & 0 & 6 & 8 \\
\hline
\end{tabular}

TABLE IX

JUNIOR HICH SOCLAL.

\begin{tabular}{|c|c|c|c|c|c|c|c|c|}
\hline Activity Itele & $\mathbf{a}$ & b & e & $d$ & $\bullet$ & $\mathbf{f}$ & 8 & h \\
\hline $\begin{array}{l}\text { Danees } \\
\text { Receptions } \\
\text { Parttes } \\
\text { PLentes } \\
\text { Dinnors } \\
\text { Banguets }\end{array}$ & 8 & $\%$ & & 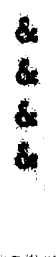 & 8 & 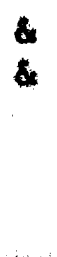 & 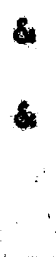 & 8 \\
\hline
\end{tabular}


TABLE X

JUNIOR HIGH STUDEN GOVERMAMT

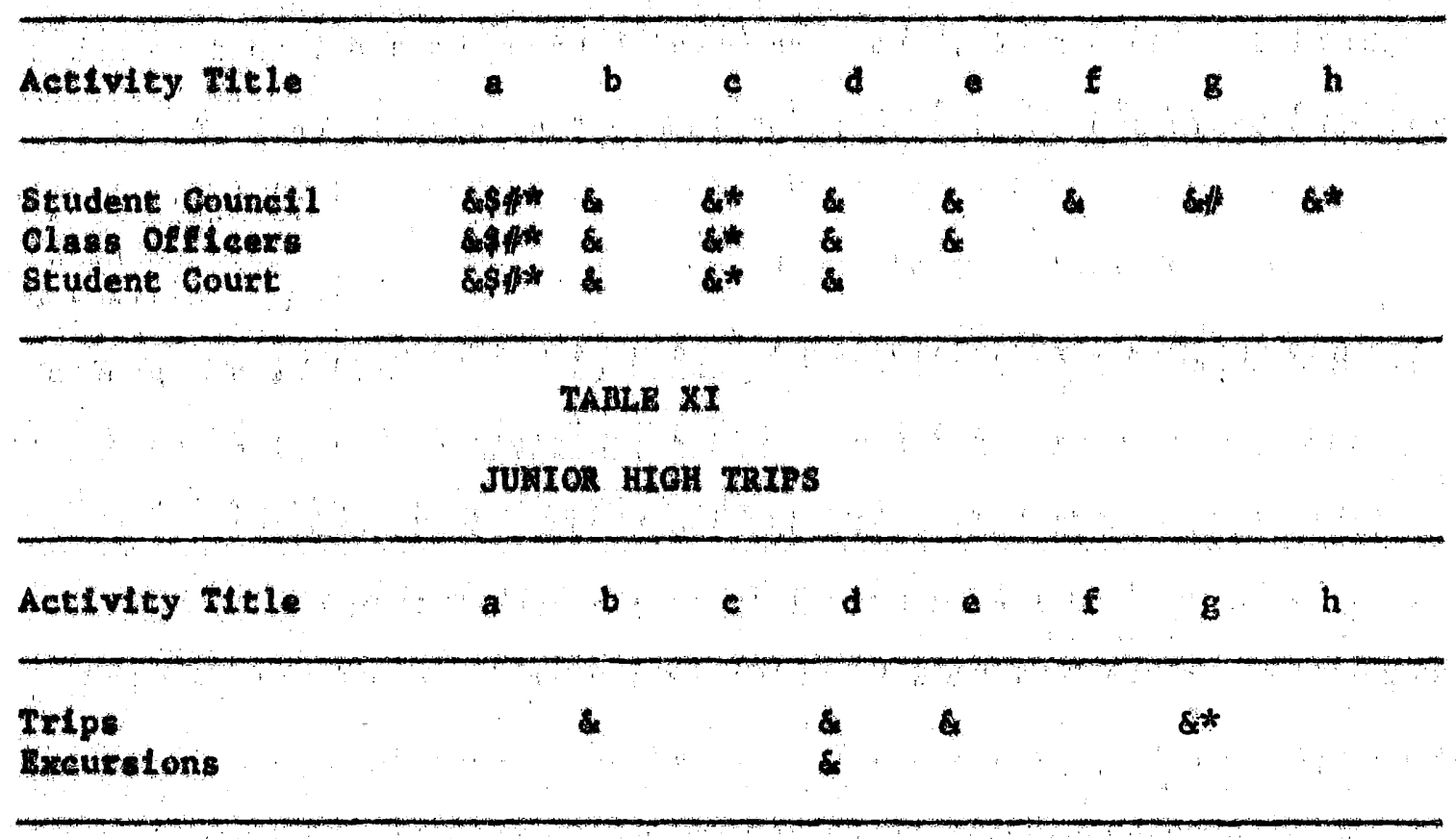


TABLE XII

JUNIOR HIGH SPECIAL INTEREST QROUPS

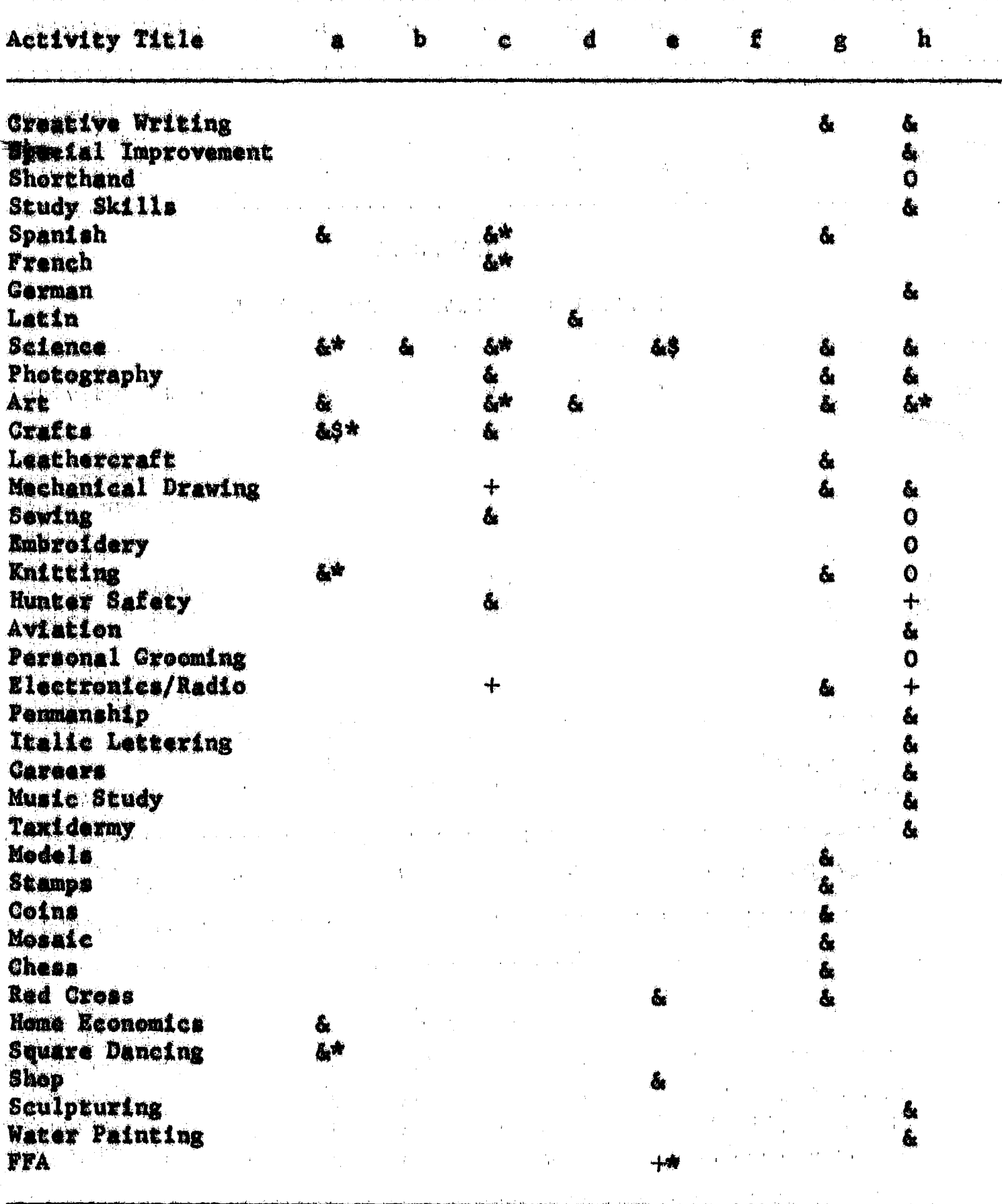


TABLE XIII

SENIOR HIGH ATHETICS

\begin{tabular}{|c|c|c|c|c|c|c|c|c|}
\hline Aetivity Title & 1 & 2 & 3 & 4 & 5 & 6 & 7 & 8 \\
\hline $\begin{array}{l}\text { Interscholast1c } \\
\text { Football } \\
\text { Basketball } \\
\text { Track and Field } \\
\text { Baseball } \\
\text { Hrestling } \\
\text { Tennis } \\
\text { Golf } \\
\text { Swimning } \\
\text { Volleybal1 } \\
\text { Softbul1 } \\
\text { Cross Country } \\
\text { SkI Racing } \\
\text { Rifle }\end{array}$ & $\begin{array}{l}+\$ \\
+\$ \\
+\$ \\
+\$\end{array}$ & $\begin{array}{l}+\$ \\
+\$ \\
\$ \$ \\
+\$ \\
+\$\end{array}$ & $\begin{array}{l}+\# \\
+4 \\
+4 \\
+4 \\
+\#\end{array}$ & $\begin{array}{l}+ \\
+ \\
+ \\
+ \\
+ \\
+ \\
+ \\
+\end{array}$ & $\begin{array}{l}+\$ \\
+\$ \\
+\$ \\
+\$ \\
+\$ \\
4 \$ \\
+\$\end{array}$ & $\begin{array}{l}+ \\
+ \\
+ \\
+ \\
+ \\
+ \\
+\end{array}$ & $\begin{array}{l}+\$ \\
+\$ \\
\& \$ \\
+\$ \\
\& \$\end{array}$ & $\begin{array}{l}+\$ \\
+\$ \\
+\$ \\
+\$ \\
+\$ \\
8 \$ \\
8 \$ \\
8 \$\end{array}$ \\
\hline $\begin{array}{l}\text { Intranural } \\
\text { Football } \\
\text { Bagketbe11 } \\
\text { Softbal1 } \\
\text { Track and Field } \\
\text { Volloyball }\end{array}$ & $\begin{array}{l}\& \\
0 \\
0\end{array}$ & & $\begin{array}{l}+ \\
\& \\
\&\end{array}$ & & & $\begin{array}{l}\& \\
\&\end{array}$ & & \\
\hline $\begin{array}{l}\text { Informal Athletics } \\
\text { Badinteon } \\
\text { P1ng Pong } \\
\text { Archery } \\
\text { Tumbling } \\
\text { Volleyball } \\
\text { Golf } \\
\text { skt Club } \\
\text { Swiming } \\
\text { Rifle } \\
\text { Welght IIfting } \\
\text { Playday } \\
\text { Athletic Assn. }\end{array}$ & $\varepsilon *$ & $0 \$ \sharp$ & $\begin{array}{l}\& \\
\& \\
\& \\
\& \\
\& \\
\&\end{array}$ & $\begin{array}{l}\& \\
\& \\
0 \\
0 \\
* \\
\& \\
\&\end{array}$ & $\&$ & $\begin{array}{l}0 \\
0 \$\end{array}$ & $\begin{array}{l}\& \\
\&\end{array}$ & + \\
\hline
\end{tabular}


TABLE XIV

SHNIOR HTCH ABSEMEL IES

\begin{tabular}{|c|c|c|c|c|c|c|c|c|}
\hline Aativity Tttle & 1 & 2 & 3 & 4 & 5 & 6 & 7 & 8 \\
\hline 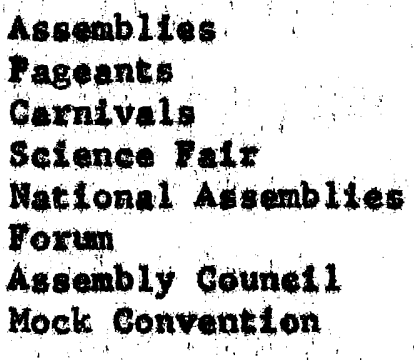 & 8 & $\begin{array}{l}8 \\
8\end{array}$ & 6 & $\&$ & 4 & 8 & 8 & $\therefore$ \\
\hline
\end{tabular}

TABLE XV

SENTOR HEH HOLEROOH

\begin{tabular}{lllllllllll}
\hline Activity fitle & 1 & 2 & 3 & 4 & 5 & 6 & 7 & 8 \\
\hline Homewoom & 6 & & & 6 & & & \\
\hline
\end{tabular}


TABLS XVI

SENTOR HICH MUSTC-BRAMA-8REBCH

\begin{tabular}{|c|c|c|c|c|c|c|c|c|}
\hline Aetivity TLEle & 1 & 2 & 3 & 4 & 5 & 6 & 7 & 8 \\
\hline $\begin{array}{l}\text { Muste } \\
\text { Vocal } \\
\text { Ghortu } \\
\text { Small Group } \\
\text { Cholr } \\
\text { Girl's olee }\end{array}$ & $\begin{array}{l}* \\
0\end{array}$ & $8 *$ & 4 & $\frac{8}{6}$ & $\begin{array}{l}\text { \& } \\
\text { o* }\end{array}$ & $\begin{array}{l}6^{*} \\
8\end{array}$ & $\begin{array}{l}4 \\
8\end{array}$ & 8 \\
\hline $\begin{array}{l}\text { In'strumentel } \\
\text { Marching Band } \\
\text { Concert Band } \\
\text { Orehestra } \\
\text { Fep Band } \\
\text { Denee Bend } \\
\text { String Group } \\
\text { sma11 Enserable }\end{array}$ & 8 & $6 *$ & $\begin{array}{l}6 * \\
+\end{array}$ & $\begin{array}{l}4 \\
6 \\
+\end{array}$ & 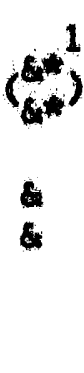 & 8 & 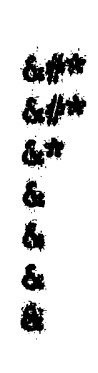 & 8 \\
\hline $\begin{array}{l}\text { Drama } \\
\text { Club } \\
\text { Oless Play } \\
\text { Stuge Graft } \\
\text { Thesplane }\end{array}$ & $\&$ & $\&$ & 6 & 8 & $\begin{array}{l}6 \\
6 \\
4\end{array}$ & $\begin{array}{l}8 \\
8.8\end{array}$ & 8 & \& \\
\hline $\begin{array}{l}\text { Speech } \\
\text { Public speaking } \\
\text { Dobate } \\
\text { Speech Glub } \\
\text { Torenstes }\end{array}$ & $\begin{array}{l}8 * \\
\&\end{array}$ & $\$ \$$ & \& & 8 & $8^{*}$ & $\begin{array}{l}6 \\
4 \\
8\end{array}$ & $\begin{array}{l}8 \\
8\end{array}$ & 6 \\
\hline
\end{tabular}

TABLE XVII

SENIOR MIOA SGHOLARSHTP

\begin{tabular}{|c|c|c|c|c|c|c|c|}
\hline Activity Ritle & 2 & 3 & 4 & 5 & 6 & 7 & 8 \\
\hline $\begin{array}{l}\text { Nattonal Honor Boelety \&\$ } \\
\text { Honor Roll } \\
\text { Honorable Mention } \\
\text { Runner up }\end{array}$ & $4 \$$ & 4 & 4 & 4 & 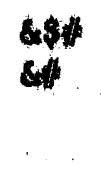 & \& & $\frac{4}{4}$ \\
\hline
\end{tabular}

IThe parenthests indicate that the "Concert Band" and the "Marching Band" are functions of the same group. 
TABLE XVIII

BENIOR HIGH PUBLICATIONS

\begin{tabular}{|c|c|c|c|c|c|c|c|c|}
\hline Activity Title & 1 & 2 & 3 & 4 & 3 & 6 & 7 & 8 \\
\hline $\begin{array}{l}\text { Yearbook } \\
\text { Nowdpaper } \\
\text { Student Handbook } \\
\text { student Directory } \\
\text { Quil1 and Serol1 } \\
\text { Student Magesine }\end{array}$ & $\frac{8 k}{6}$ & $\varepsilon^{4 * *}$ & 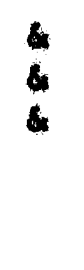 & $\varepsilon$ & $\begin{array}{l}8 * \\
8 *\end{array}$ & $\frac{6}{6}$ & 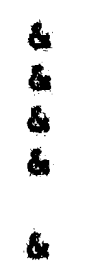 & 8 \\
\hline
\end{tabular}

TABLE XDX

BEHIOR HIOH SBRVIOE AND WELFARE

\begin{tabular}{|c|c|c|c|c|c|c|c|c|}
\hline Aetivity retle & 1 & 2 & 3 & 4 & $\$$ & 6 & 7 & 8 \\
\hline 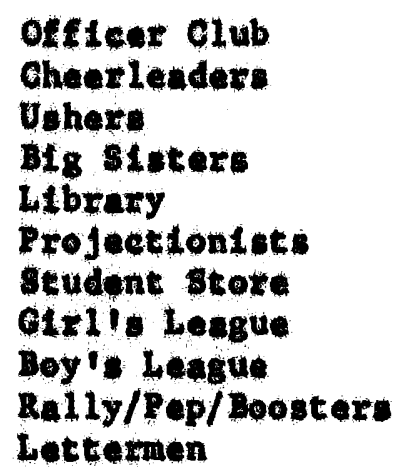 & $\begin{array}{l}\text { 예 } \\
* \\
+ \\
+\end{array}$ & $\begin{array}{l}0 \$ \\
6 \\
4\end{array}$ & $\begin{array}{l}0 \\
0 \\
0 \\
+ \\
4 \\
0 \\
0 \\
+1\end{array}$ & $\begin{array}{l}0 \\
+ \\
0 \\
+\end{array}$ & $\begin{array}{l}4 \\
4 \\
0 \\
8 \\
+4 \\
0 \$ \\
0 \$\end{array}$ & $\begin{array}{l}+* \\
8 \\
0 \$ \\
+\$ \\
0 \$ \\
+4\end{array}$ & $\begin{array}{l}+ \\
0 \\
+ \\
0 \\
+\end{array}$ & 4 \\
\hline
\end{tabular}


TABLE XX

SENTOR MICH SOCLAL

\begin{tabular}{|c|c|c|c|c|c|c|c|c|}
\hline Activity Title & 1 & 2 & 3 & 4 & 5 & 6 & 7 & 8 \\
\hline $\begin{array}{l}\text { Dences } \\
\text { Receptions } \\
\text { Parties } \\
\text { Dinners } \\
\text { Benquets } \\
\text { Glass Might } \\
\text { Sentor Dey } \\
\text { sentor Trip } \\
\text { Becealaurate } \\
\text { Graduation } \\
\text { sentor Bass } \\
\text { Juntor Prem } \\
\text { Juntor-Sentor Prom }\end{array}$ & $\begin{array}{l}\mathbf{8} \\
8 \\
8 \\
6 \\
6\end{array}$ & $\begin{array}{l}4 \\
4 \\
4 \\
4 \\
4\end{array}$ & 8 & $\$$ & $\begin{array}{l}8 \\
8 \\
4 \\
4 \\
4\end{array}$ & $\begin{array}{r}48 \\
48 \\
48\end{array}$ & $\begin{array}{l}4 \\
\& \\
\& \\
\&\end{array}$ & $\begin{array}{l}6 \\
0 \\
8 \\
8\end{array}$ \\
\hline
\end{tabular}


TABLE XXI

SENIOR HIOH SPECIAL IMTEREST

\begin{tabular}{|c|c|c|c|c|c|c|c|c|}
\hline Aetivity Mte & 1 & 2 & 3 & 4 & 5 & 6 & 7 & 8 \\
\hline 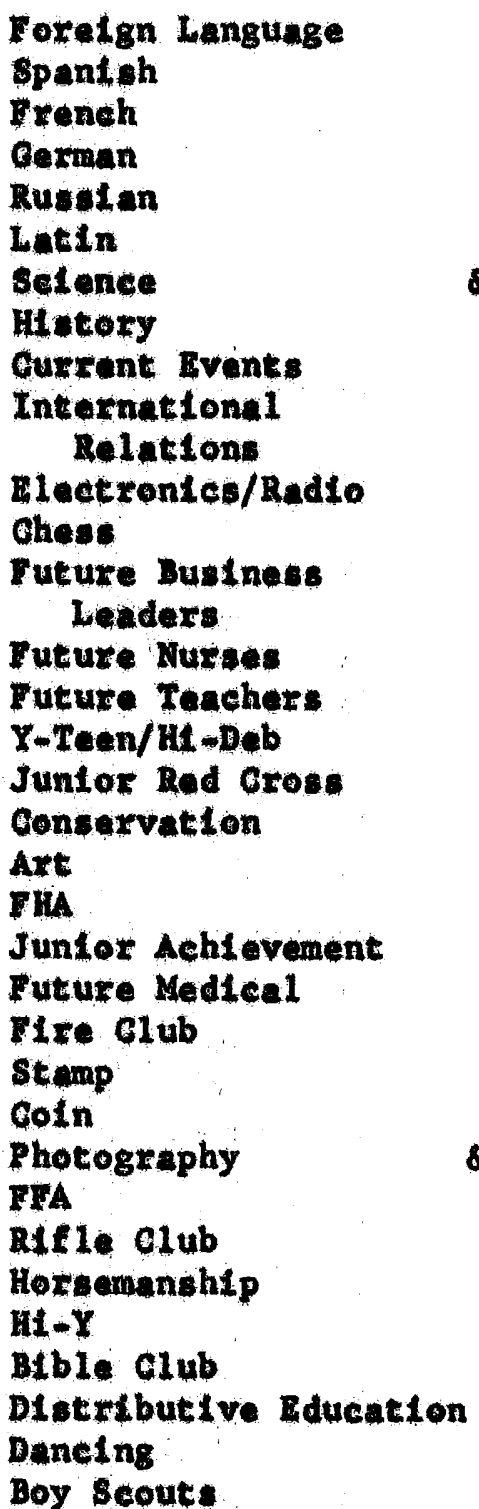 & $\&$ & 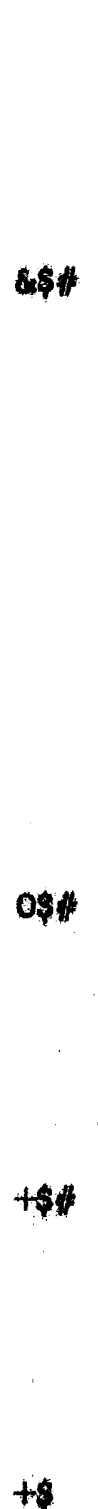 & 8 & $\begin{array}{c}\alpha \\
6\end{array}$ & $\begin{array}{l}+ \\
+\$ \\
\& \\
+\$ \\
\&\end{array}$ & $\begin{array}{l}4 \\
4 \\
4 \$ \\
0 \$ \\
4 \\
4 \\
4 \\
4\end{array}$ & $\begin{array}{l} \\
4 \\
6 \\
0 \\
8 \\
8 \\
\end{array}$ & $\begin{array}{l}4 \\
4 \\
4 \\
4 \\
4 \\
4 \\
4 \\
4 \\
4 \\
4 \\
4\end{array}$ \\
\hline
\end{tabular}


TABLE XXII

SENIOR HIGH TRIPS

\begin{tabular}{|c|c|c|c|c|c|c|c|c|}
\hline Aetivity Title & 1 & 2 & 3 & 4 & 5 & 6 & 7 & 8 \\
\hline TrLps & $\Delta$ & 8 & 6 & 6 & $8 *$ & * & $\&$ & \\
\hline
\end{tabular}

TABLE XXIII

SEMTOR HIGA STUDER GOVERMMEX

\begin{tabular}{|c|c|c|c|c|c|c|c|c|}
\hline Aet Ivity Itele & 1 & 2 & 3 & 4 & 5 & 6 & 7 & 8 \\
\hline 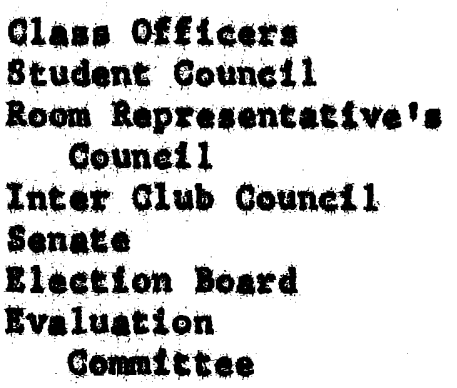 & 4 & 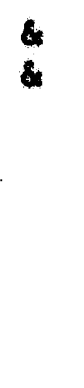 & 8 & 4 & 6 & 6 & 4 & $\begin{array}{l}\Delta \\
4\end{array}$ \\
\hline
\end{tabular}




\section{CHAPTER VI \\ SXNOPsIs or FIELD IMVSstiextion}

The purpose of this ehipter ts to present a conctse roview of bome of the stetfstical dath presented in the fortgotng pages. The material 1s orgentied in the same way as the tables. That is, a discusston of the junlor high activities, arranged in the seme oxder as the tables, is prosented firat. This is followed by discusaton of the sentor high activities arranged in the ane anner. All teforences are mude to the activittes by thetr titles as they appear in the tables.

\section{Juntor Helh Achletteo}

Three ochodls (twe of these are the largest juntor high sechools in the study) do not partielpate in any Interieholastie athletic

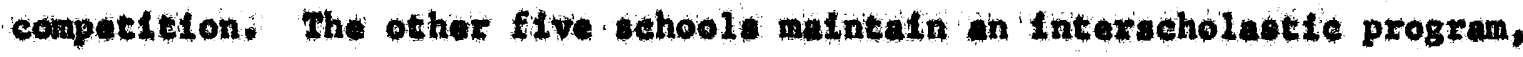
malniy for boys, which usually requitre some financlal inventment. One mehool offers an extenelve Interseholentte program and a vary IImited intranural or Informal whletto progran. Tean and other highly organtzed eports donfrite over Individual and Informally structured ectivities. Juntor Hgh Ageremblics

All Wahington Gounty junlor high schools offer a program of assemblles to thetr students. 
Juntor High Homeroom

Three of the etght funtor high shools offer the "Homeroom" activity. The two laxgest school feel that the "Homeroon" expertence 1. valuable anough to have the activity in thetr program. Juntor High Mug1e-Dromi-Speech

The number of Wesal Huste" opportunttles nelther Incresee nor decrenses according to school size. The same is true with instrumental Muste." Activities in "Brama" are scuttered; no chance for this type of axpertence is found in two of the sehoels studied. "speechn setivities are lso senttured. Two chools do not offer "Speech," However, each juntor high sehool does offer at least one activity in etther "Bpech" or "Drama," The overall pleture of thls ectivity area shows that, generally, an increase in gehool siwe doeo not necesenfily mean an Incrase in the vartety of the activitios offered. Junior High Publications

The aetivitios in this fleld are generally evenly distributed wth the amaller school varying in the opportunttes offered. Al1 of the schools provtde for some newpaper type of activity; half lsoue adedente credtc for this work. Juntor Heh Sebolarship

All school save orie malntatn some type of seholarshtp racognttion activity. The majortty (stx) of the schools use thetr own "llonor Roll" system, while two of the schools maintuin association wh a national organization. 
Juntor Hgh service and Welfiere

The imallex sehools offer more opportunities, generally, than the larger ones. Five schools each offer activitles for "cheerleaders," "Projectionists;" and "Echool store" personnel. Notice that girle only are allowed to panticlpate in "choorleading;" the sehools that do not partielpate in intoracholastie athletie comptition lso do not have "Oheerleaders,"

Juntor Hgh Sodtal

"Dances" and "Rartles" are the wost frequentiy 11sted soclal activites. One school Itete no soetdi hetivitles at all, whlle seven hold "Dandes" ind flve engage in "partles," There aro no restrictions In the soctal detivittes on the bests of sox.

Juntot Hilg Student Governint

The smaller behools offer wore detfvitles in thls ared than the larger ones: Thus; in the area of leaderohlp tralning and demoeratic responslblitty, opportunftles are more reddily avallable In the emiller chools: All of the Investigated juntor high schools malntain a istudent Counct1" and flve have "Cldss offleere" orgentation.

\section{Juntor High Trtes}

Trtps and excurstons are utflised in fifty percent of the whohington County juntor high schools:

Junlot Hgh Spectal Interege Croupe

In this eategory the large shools deminate the varfety of offertings. One school offers no spectal interest activitles, another offors one, another offere three and yet another offers only four. The two most 
frequently sponsored clubs are "Sclence" and "Art;" both are sponsored In five chools. The vast majority of these activities are open to both boys and gits.

\section{Sentor Hgh Achlettes}

The Interscholestle progran is extenatve. Predietably, the larger schools offer greater verlety of actultles and great majority of these activities are for boys only. However, there are sone activities for glrle at this level.

Only three schools offer an incramural program and the Informal activities are scattered. Some schools offer an oxtensive infomal program whlle others have few activictes, Whereas the boy dominate the Interveholatic activitles, the glxle are given the greater share of the Informal athletle opportunities. Sports which require some extenutve personal Investment of money (okiting, rifle practlee, and golf) are found malniy in the larger schools.

The overall pleture appears, as in the case of the junior high school activities, to favor the tem and other highly orgenised uthlet fe expertences. Conerally, the number of offexings docs not increase with the stwe of the sehool except in the competitive interscholastle oports. SenLor High Acaemblles

All of the high schools queetioned offer some sort of assemblytype program. Moot of the high schools (six) offer more than one assumbly aet I vity.

\section{Sentor: Hgh Honeroom}

Only two of the high sahools matntaln "Homeroom" activity. 
Sentor High Mustc-Drana-Speech

In "Mutic," Mrama," and "Speech" the trend 18: The larger the school, the grenter the number of activities offered. This is espectally true in the area of Instrumental muste.

All of the schools operate one or more vocal muste cetivitias; the "Ohorus," which gives opportuntties to both boys and glrls, Is to be found In each of the schools canpled. S1x of the elght schools grant academic credit for this activity and half of the schools allow academic credit to be esrned for one other voeal mustc expertence.

Again, as in the case of vocal muale, instrumental music is represented in each of the schools by a commen title-m-Band," This may be ather "Marching" of "Goncert" or somotimes both. Further, this ectivity is used to carn acudemic credt in $1 x$ of the elght schools investigated, in fact, thay are the very same schools that do this in the voeal wuste area. Seven of these etght sehool offex more than one Instrumental musle activity; one sehool offers as many as seven such opportunitles. Only the two lergest school offer norchestra," but seven offer "Pep Band" and five have an organized "Dance Band."

In drama activities, all of the Washington County high whools have some offering. Soven of the shools prosented "Olass Plays" and five have organited "Thesplang" clubs. None of the schools reported that particlpation in these activitiea earns acadenic credit.

All of the sampled high schools offer some speech activity. Most of the schools (seven) use "Public speaking" as thetr matn speech activity and flve of these Institutions hold " "Dabate" activity. Fow of the speech activities earn academic credtt. 
Sentor Hith Seholerchlp

The "Wationd Honoz Soetety" scholarship aetivity is found in all of the high schools and the "honor Roll" ts found in weven of the sehools. One school hes four activitles classffied as scholurship in nature. Sentor High gublications

The publications activities are represented in all of the schools by both the "Yoarbook" and the "Wowepaper" wth half of the sehools allowing acidemic erodit to be earned for such partielpation. six out of afght of these sehools alse publimhed "student Handbook." In contrast with the junior high schools, the high schools pubitin a "student Directory" In only two eases, whle the younger chool group do so In thzoe Instances. In both communtties, this ectvity is engaged in by the larger schools. Conerally, the 1arger the school, the greater the vartety of opportuntties offered.

\section{Sentor High Servied and Helfare}

The service elubs and welfare groups appear to be orgented for particlpation by glrls of boys done on latgex seale than in any other activity group axcept for athlettes. Such activities at metteman," "Boy's League," and "Projectiontats" are Instituted for the boys, whilo the gtrls' activteles Inelude Hally/Pep/Boosters," "Girl's League," and

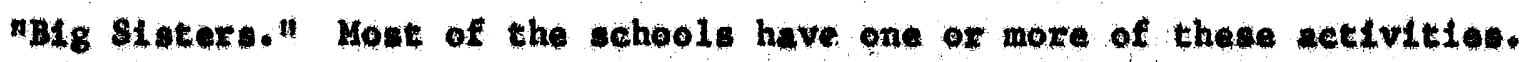
Only one activity in this aroup is found In all the sehools--"Cheerleading." Alvo, in half of the schools the activity is open to glels only, in the other half (matniy the larger Inatitutions) efther boys or givls may partiefpate. 
Perhaps the most complex set of partielpetion factors is found In the group of Hokers:" Stx schools offex this opportunity. In three of these, both boys and girls may attend, in two only girls may partictpdte, ind in the last school to offer this opportunity, only boys mog take part:

\section{Sentor High Soclal}

An examinition of the tabuletions of this study indieates that in cerms of vartety of detivities, those of a boctil nature are the most evenily distributed throughout the behools. All of the schools offer "panees" (Informal), "Bacealautoute," and "oraduation." A majorlty of the questoned sehools hold "Parties" and "Banquets" for their students.

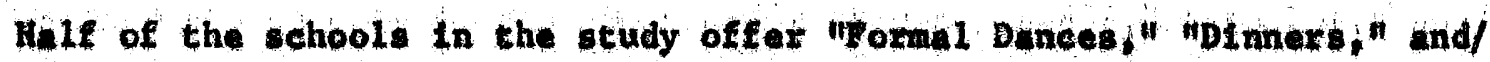
or "Reesptions "

\section{Sentor Migh Spectol Interest Croups}

What wes true in the juntor high sehools is aloo true in the high sehools--the sehools of a lerger population offer more special interest activities then enaller sehools. The most frequently offered adtivities are "Sctence," "Internutional Reletions," undio/Blectrontas," and "Jumbor Red oross," Fow of these setivitios are limited to partiatpation by baye of glris only.

\section{Sentor Hgh Trtps}

Seven of the eight questioned wchool participate in nixips."

\section{Sencer High gudent Governoent}

Al1 of those schools malntain at least two government activities-"Class offleers" and "student counct1," The three largest chools add one or two more such activities. 


\section{DIBLIOGRAPHY}

Constitution and By-lave. Rortland: Ozegon school Aetivities Assoctation, 1964.

Frederiek, Robert W. The Thixd Curzieulum. Wow York: AppletonCentury-Grofts, 1959.

Fretwell, Elbert $\mathrm{x}$. Extre-Currteular Aetivitlet. Boston: Houghton Miffin, 1931.

Grahan, Grace Htudent Activitieg-An Ovovilaw and Rationale, The Dulleten of the Hational Ascogletion of Secondary-sehool Peineipals, Oetober, 1964.

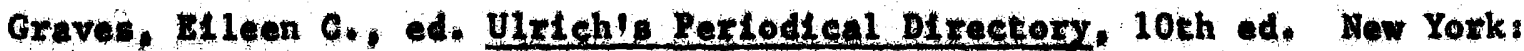
R. R. Bowler, 1963 .

Gulde to Juntor High Sehool Edueation in Orogon. Salen: state Department of Edueetion, 1963.

Gulde to Secondery Eduegtion in Oregon. Salem: State Department of Heveation, 1961.

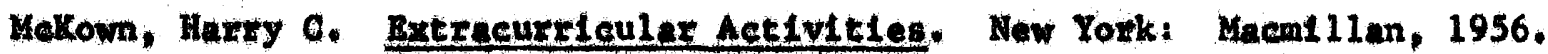

Millex, Frank1Ln A., James H. Hoyer, and Robert B. Patrick, Rlenning student Activitles. Bnglewood Cliffs: Prentice-Hall, 1956.

Mock, Albort A. A Manual of student Aetivities. IndLanopolls: Albert Mock, publisher, 1952.

1964-65 Oregon School Directory. Salen: State Department of Education, 1964 .

Unruh, Adolph, "Improving Extra-class Aetivities," School Adtudteles, Januaxy, 1964.

Ton, John F. "What do Activities Contribute?" School Aartuteles. september, 1963. 


\section{GUPPLEMRMTARY BIBLIOGRAPHY}

Campbe11, Larrence R. "Co-Gurrtcular Aetlvitles--success or Fallure?" Behool Adetvitles. December, 1961.

Sehool Act1vetes, November, 1963.

County and CLty Beta Book, 1962, Washington: U.s. Bureat of the Cenisus, 1962.

Eveluntive Geferti. Weshington: Cooperative study of Secondary Sehool Seandate. 1961.

Johnson; Sdger 6. and Roland 6. Vaunce. Student Activitles in secondary Sehools. Hew Yorkt The Roland Press, 19K.

Lundgren, Herry. ' Teaching Morallty Through the Extracurxleulundit School Aativicles. September, 1963.

Oregon Covered Bnolorment and Bayzo $11 \mathrm{~s}$ by Industry, County, and Month. 1963. Salemt Ozegon State Department of Employment, 1964.

Population Brtimater of Countles and Incerporated Clt1es of Oregon, July 1, 1963. Fortiend: Oregon State Boexd of Centus.

Reed, Bruce M, Rutra-Class Activities as Bchool-Comuntty Brtdge Bul1dezs, School Actidt tes. Decenber, 1961.

Sukalac, Peter G., d. Qzezon 1965-1966 Blue Book. Sulems, Secretary of state, 1965.

sukhomilnskti, V. A. peveloping Individual Abilities and Inclinations In schoolchlidren," Soviet Bduettion, December, 1963.

Terry, Paul W. Supervlelng Batre-Gurteular Activit1es. New York: McGraw-HL11, 1930,

Thompson, Nell1e Zetta. Youx School Clubs, New York: E. P. Dutton, 1953.

Tompkins, Bllsworth. The Activity Porlod In Bublic W1gh Schools. Washington: Federal Security Agoney Offlee of Educntion, 1951. 
Wiles, Kimball. The Changing CurrteuIun of the American High School. Englewood C1fffs: Prentlee-He11, 1963.

ZImmerman, J. Richard, "Please Don't Say No' to the Bxtracurnteular Rrogram." School Activitles, January, 1964. 
APPENDIX

QUESTIONNAIRE USED IN THIS STUDY 


\section{Washington County Secondary School Activities Questlonnaire}

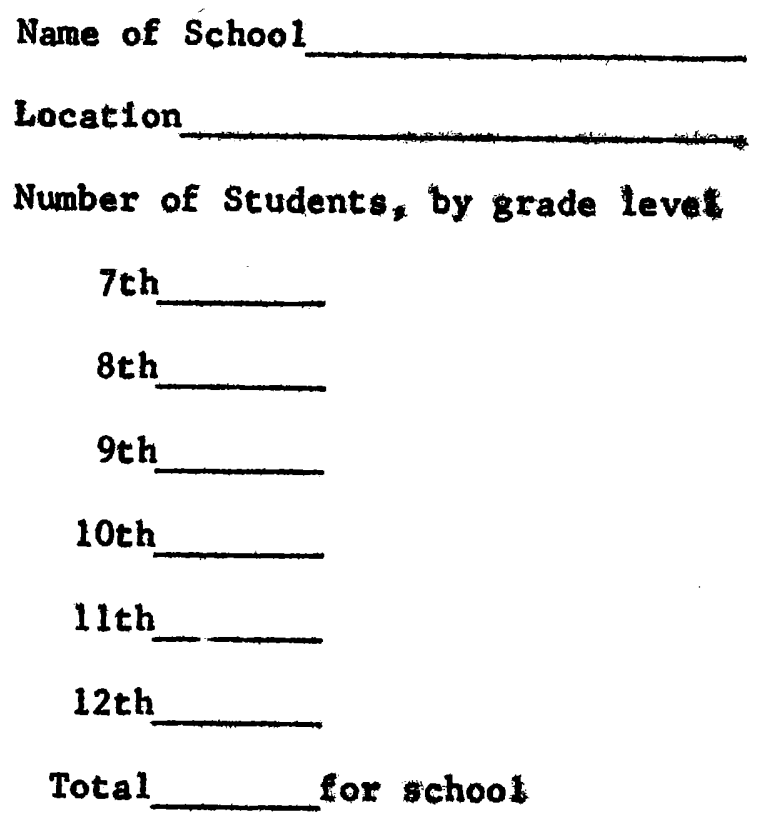


Limiting Factors -- Please check ( 15 if applicable

Scholarship,

Government,

Welfare

Activity Title

Officer Club

Cheerleaders

Ushers

School Patrol

Big Brothers

Big Sisters

Library Club

Projectionists

School Store

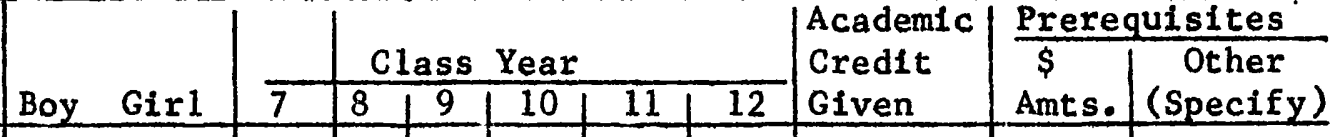


Service, Limiting Factors -- Please check $(V)$ if applicable

Scholarship,
Government, |Academic| Prerequisites

Welfare

Activity Title

Nationa 1

Honor Society

Honor Ro11

Student Court

Class officers

Student Council

Homeroom 
Co-operatively Limiting Factors - Please check $(W$ if applicable sponsored activities

Activity Title

Jr. Red Cross

Boy Scouts

Camp Fire

Dist. Education

4-H

FHA

FFA

Gir1 Scouts

Junior Achiev.

Key Club

\begin{tabular}{|l|l|l|l|l|l|l|l|l|l|l|}
\hline & & \multicolumn{4}{|c|}{ Class Year } & $\begin{array}{l}\text { Academic } \\
\text { Credit } \\
\text { Given }\end{array}$ & $\begin{array}{l}\text { Prerequisites } \\
\text { Bmts. }\end{array}$ & $\begin{array}{c}\text { Other } \\
\text { (Specify) }\end{array}$ \\
\hline
\end{tabular}




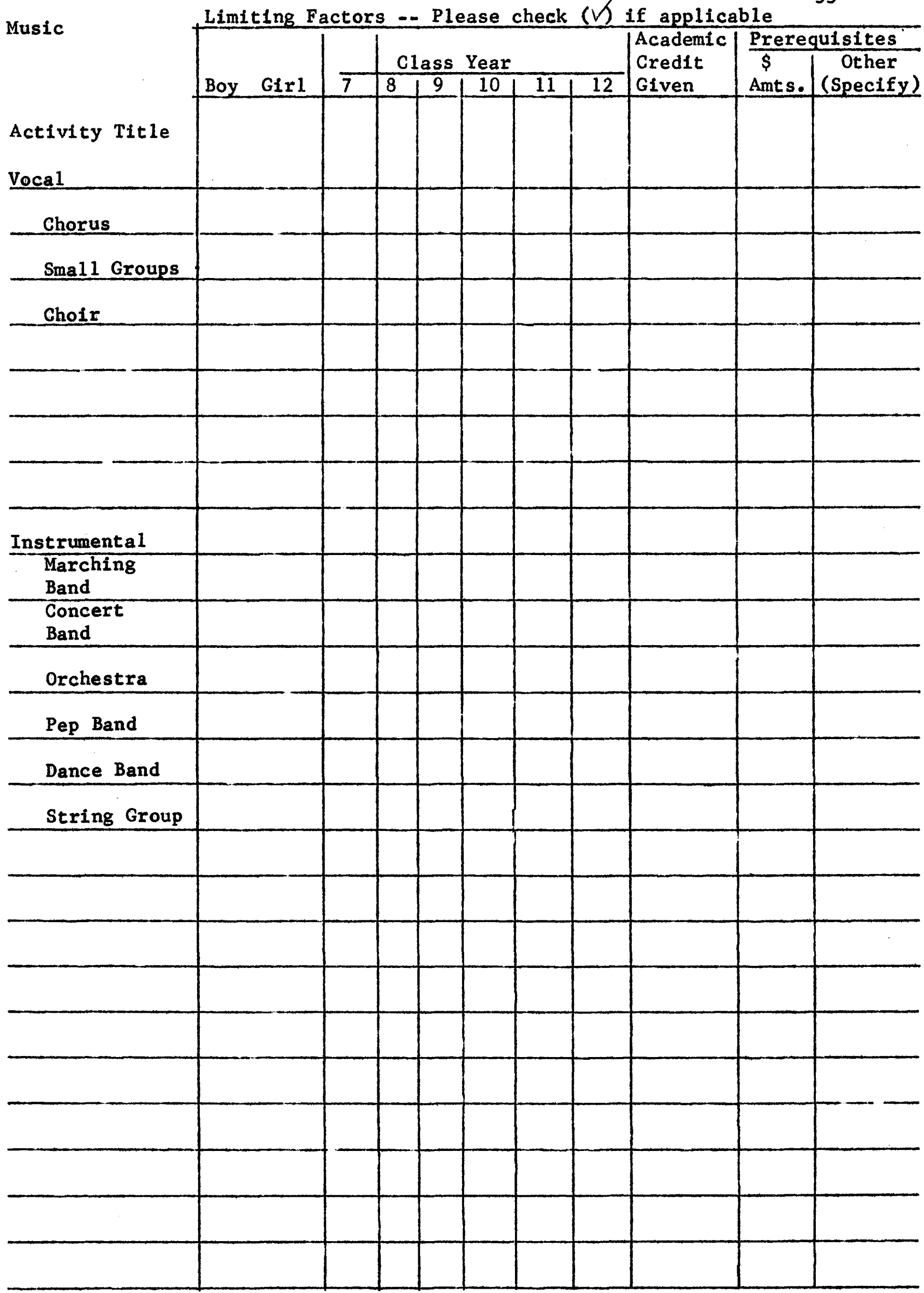




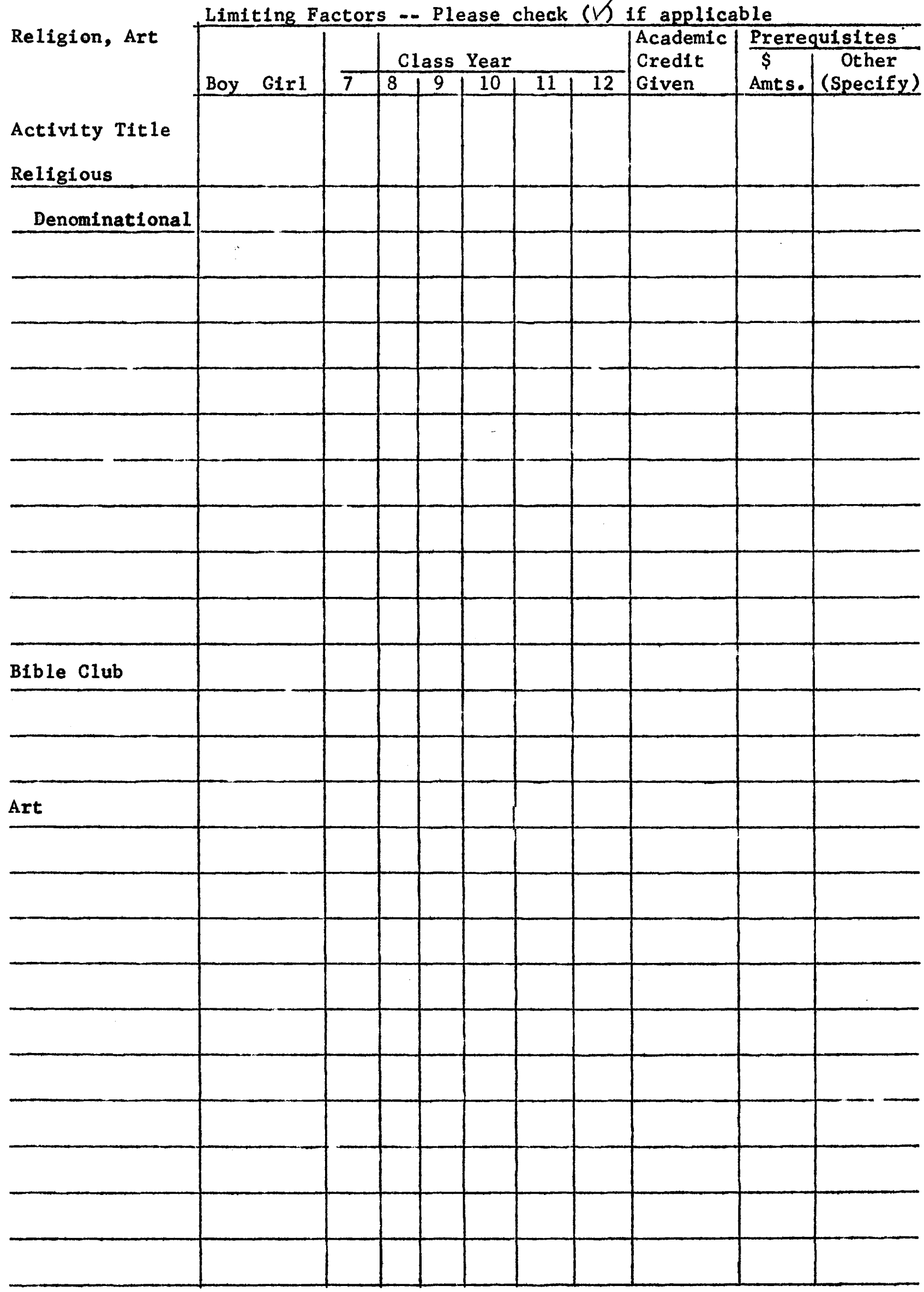




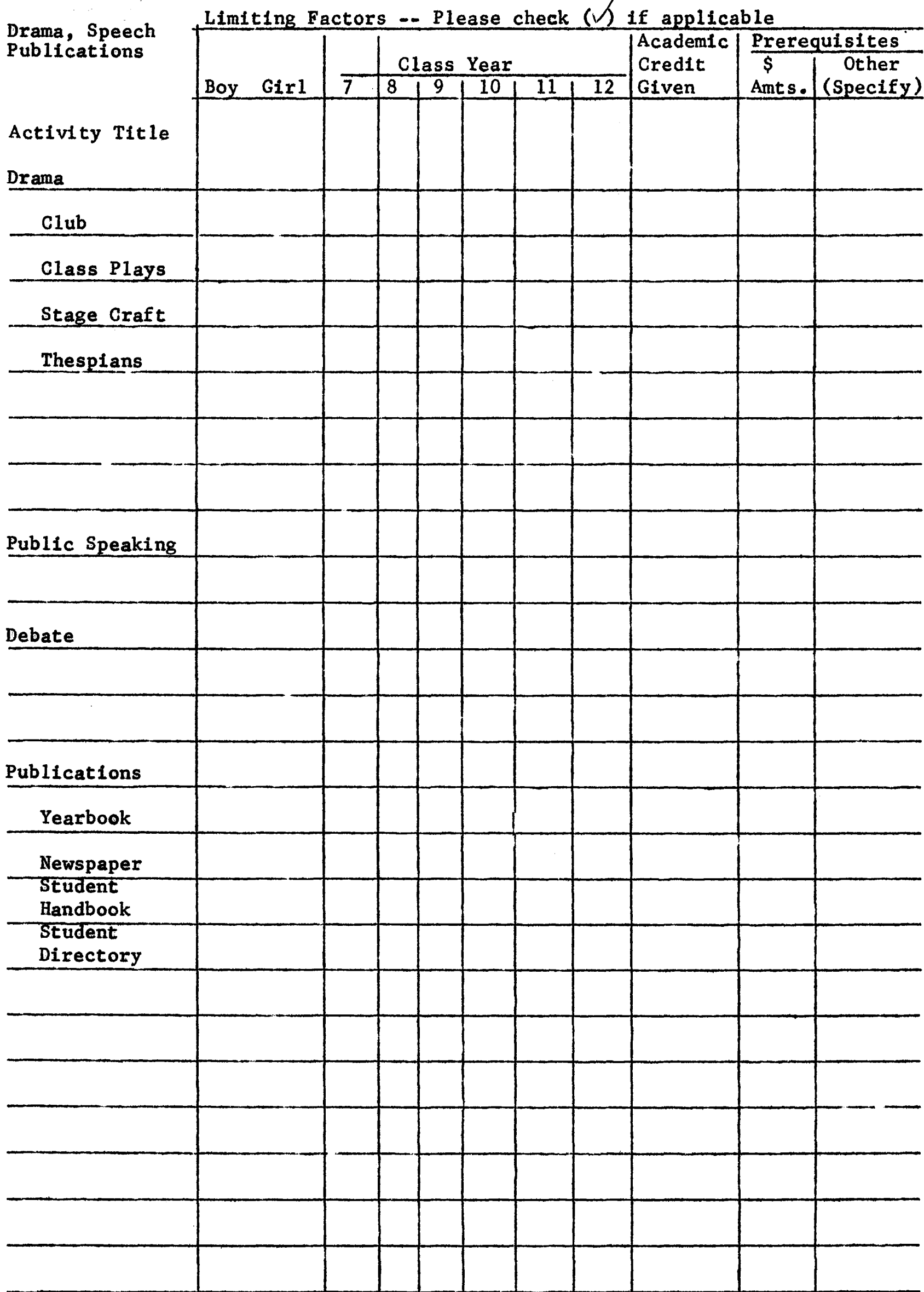




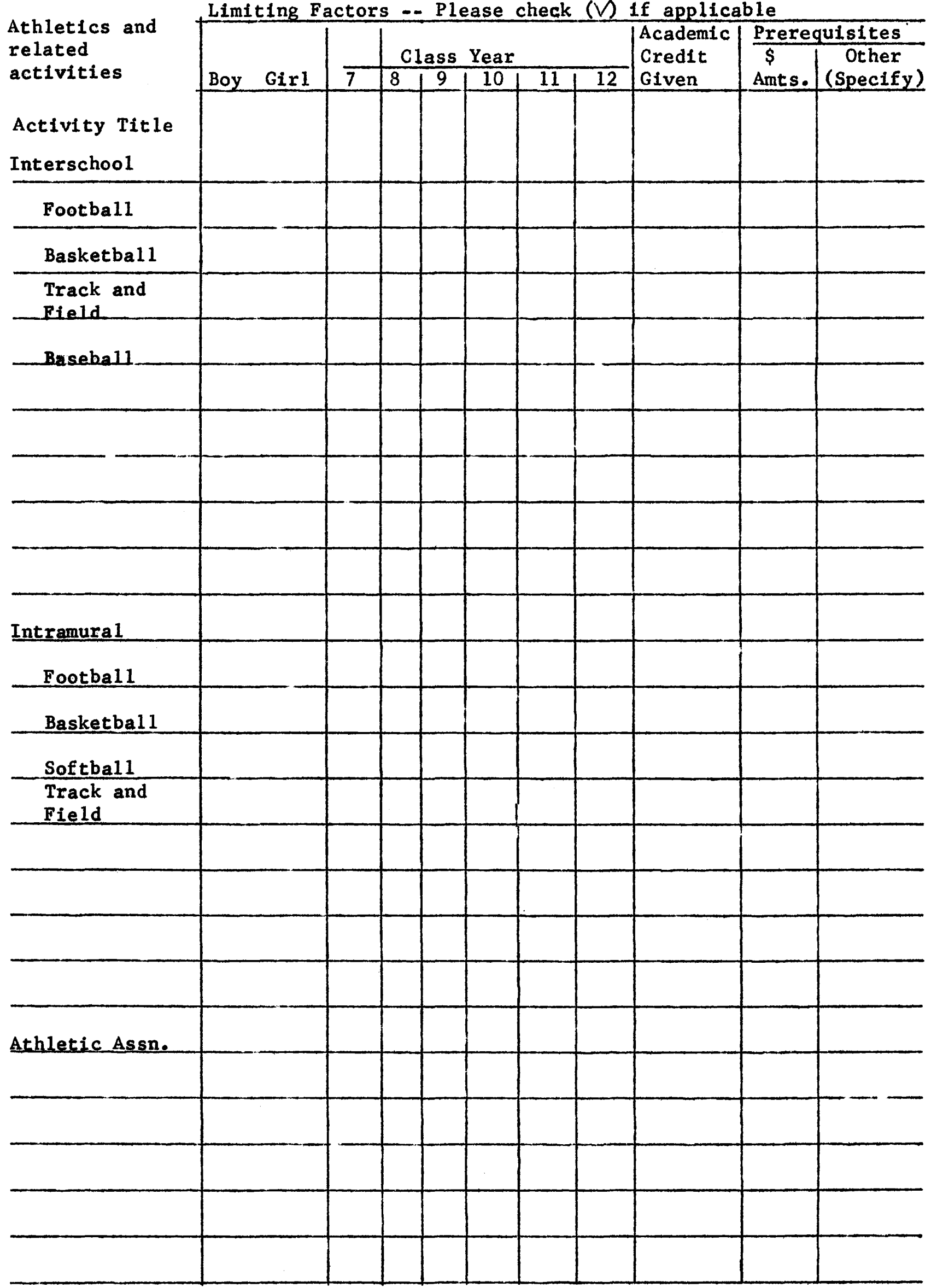


Athletics and related activities

(cont.)

Limiting Factors - - Please check (V) if applicable

Activity Title

Informal Ath.

Badminton

Ping Pong

Archery

Tumbling

Vo1leybal1

\section{P layday}

\begin{tabular}{|c|c|c|c|c|c|c|c|c|c|}
\hline \multirow[b]{3}{*}{ Boy } & \multirow[b]{3}{*}{ Gir1 } & \multirow[b]{3}{*}{$\overline{7}$} & \multirow{2}{*}{\multicolumn{4}{|c|}{ Class Year }} & \multirow{3}{*}{$\begin{array}{l}\text { Academic } \\
\text { Credit } \\
\text { Given }\end{array}$} & \multicolumn{2}{|c|}{ Prerequisites } \\
\hline & & & & & & & & & Other \\
\hline & & & \begin{tabular}{l|l}
819 \\
\end{tabular} & 10 & 111 & 12 & & Amts. & (Specify) \\
\hline
\end{tabular}


Socia1--Dinners, Limiting Factors -- Please check $(V)$ if applicable

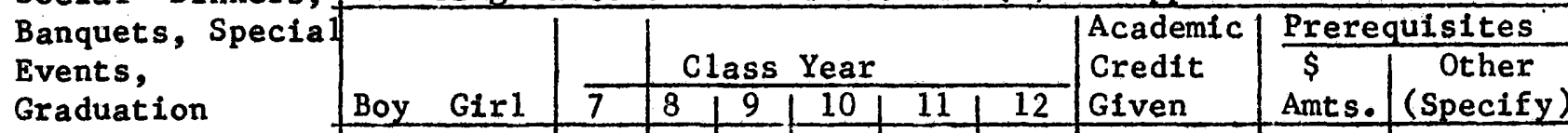

Dances

Receptions

Parties

Pianics

Dinnexs

Banquets

Assemblies

Fairs

Pageants

Carnivals 


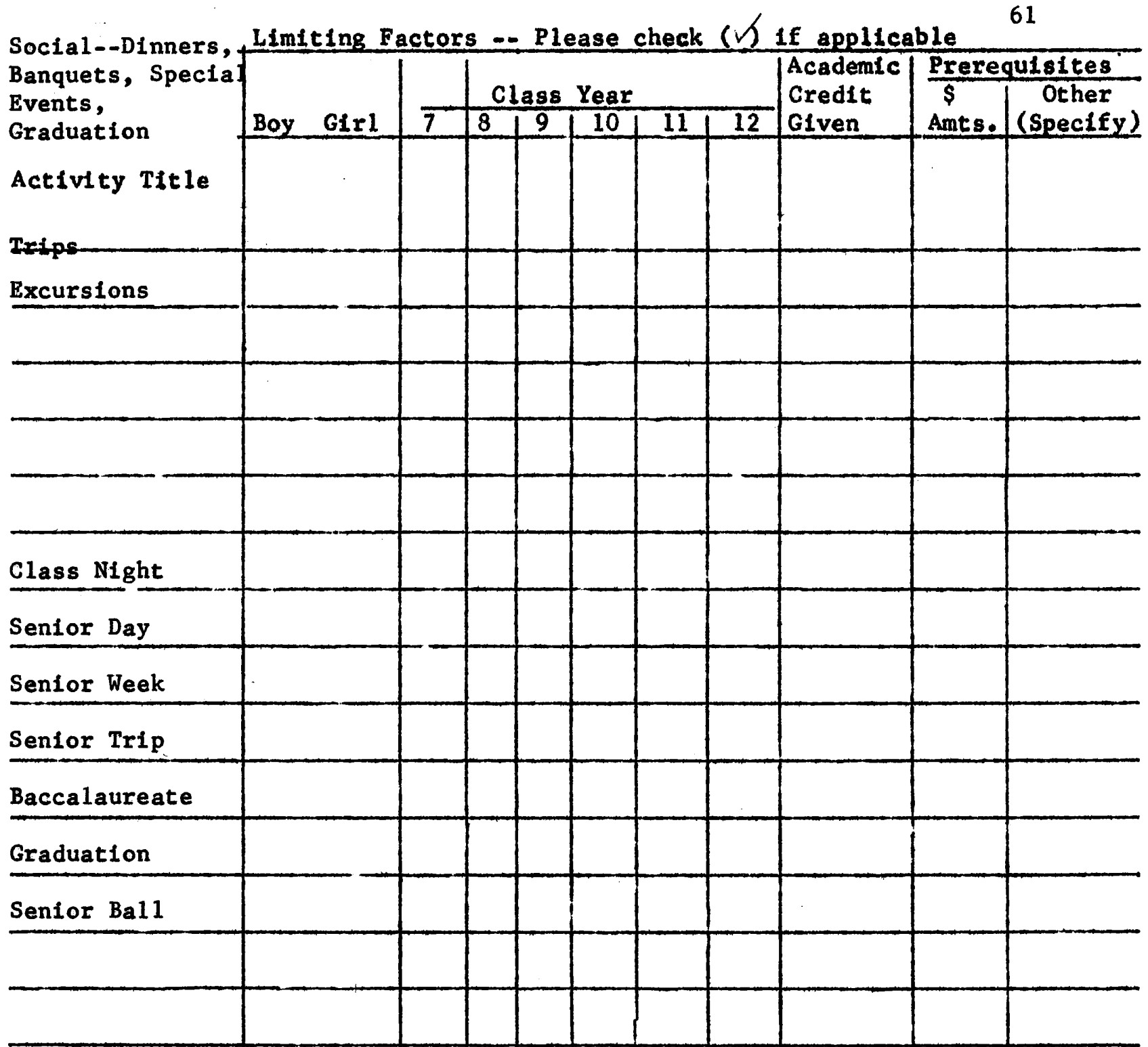


Subject Area Activities

Activity Title

English

Poetry

Book Club

Creative

Writing

\section{Foreign Language}

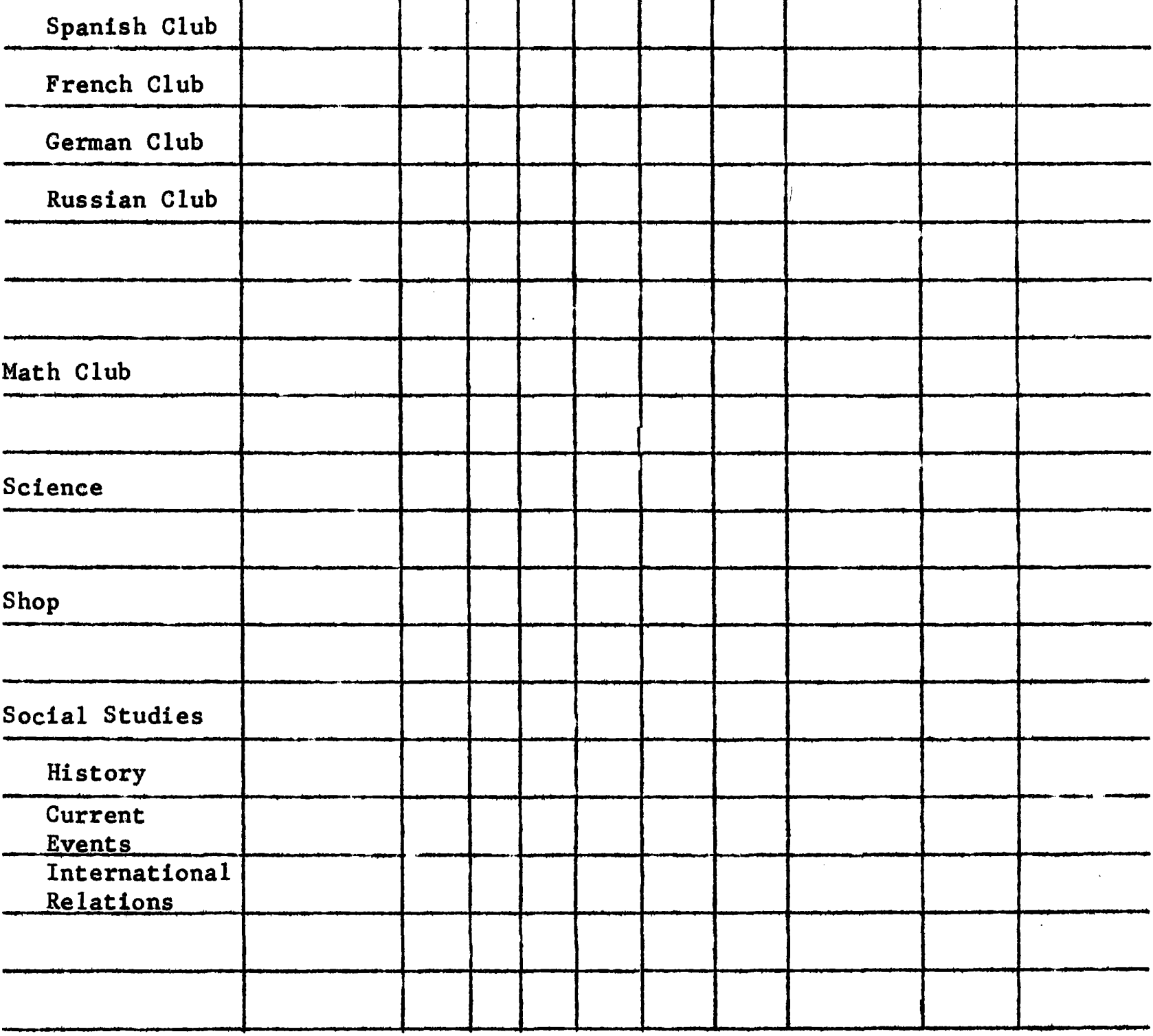




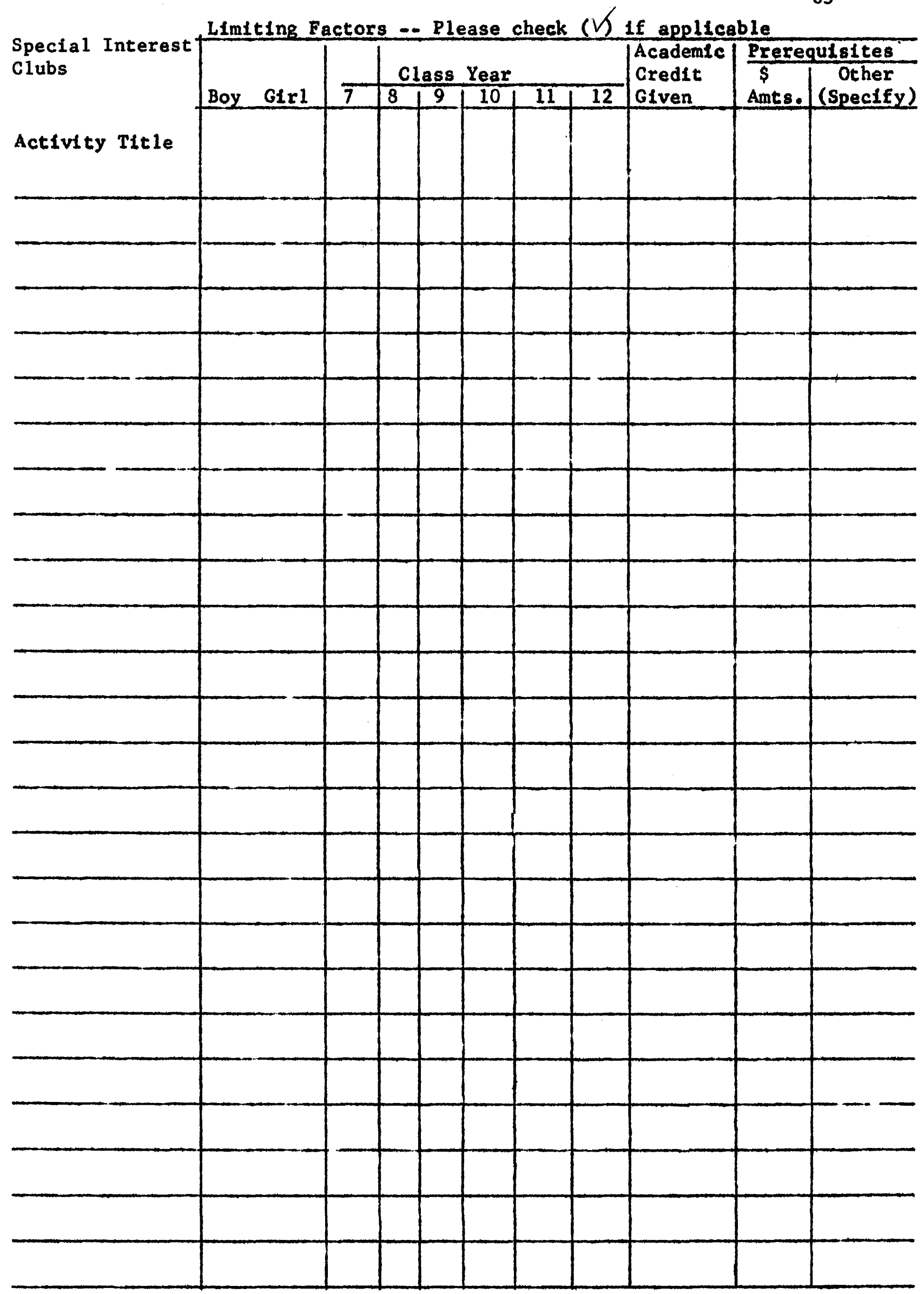




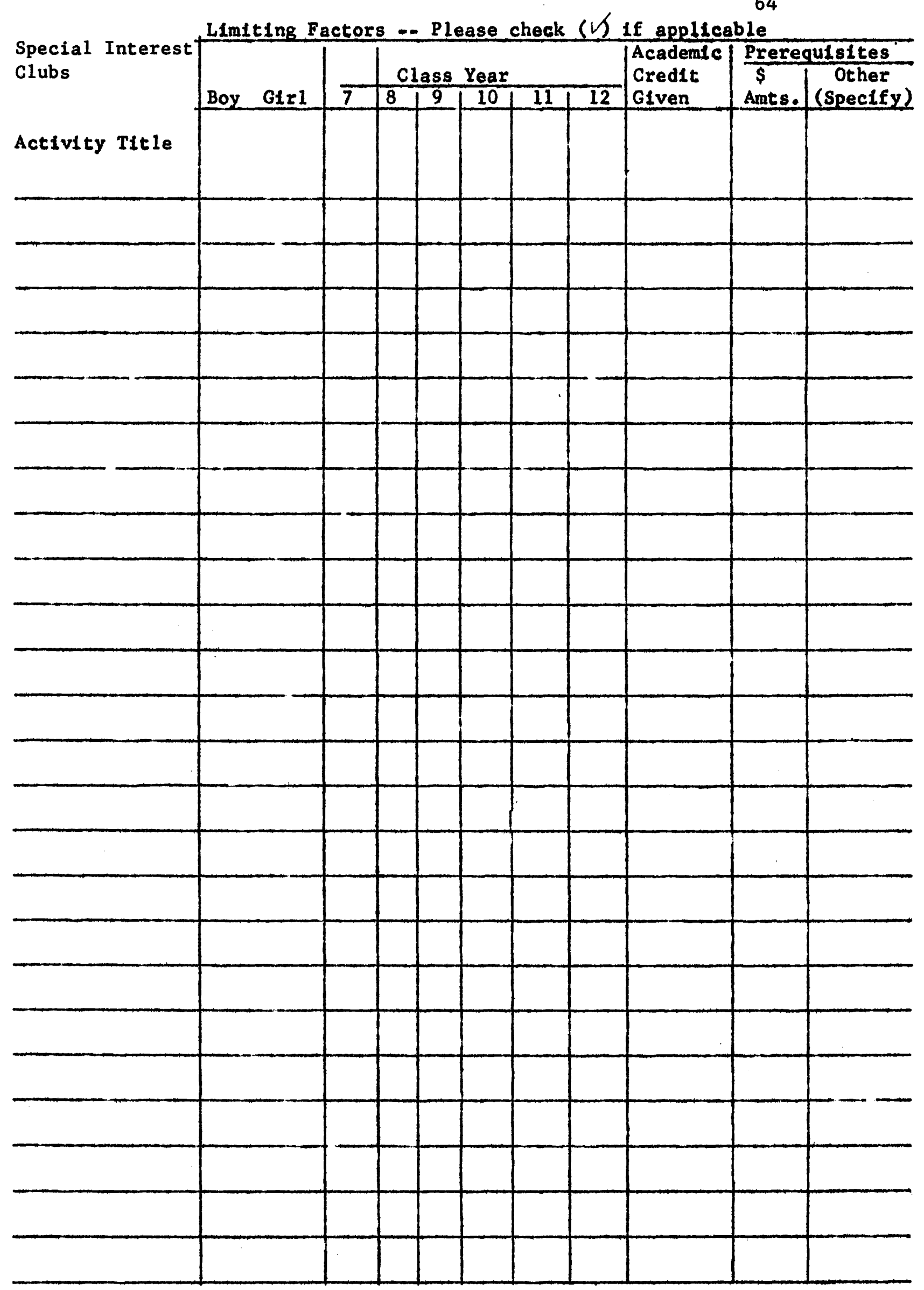

